\title{
The "Good Soldier" Defense: Character Evidence and Military Rank at Courts-Martial
}

\author{
Elizabeth Lutes Hillman
}

\section{INTRODUCTION: RANK AND ITS PRIVILEGES}

In 1998, the court-martial of former Sergeant Major of the Army Gene McKinney focused national attention on the "good soldier" defense. McKinney's adroit use of his past service as a "good soldier" was widely credited for his acquittal on all charges of sexual misconduct, in spite of damning testimony from six servicewomen about his alleged harassment. ${ }^{2}$ The McKinney trial, combined with a series of sex scandals involving the

1. See, e.g., All Things Considered: McKinney Sentenced (NPR radio broadcast, Mar. 16, 1998) ("The defense once again . . . raised the good soldier defense.") [hereinafter All Things Considered]; Morning Edition: McKinney Trial Update (NPR radio broadcast, Mar. 11, 1998) ("While [McKinney's counsel Charles] Gittins did try to rebut the 19 allegations point by point, he mainly relied on McKinney's record, the so-called 'good soldier defense."'); see also Bill McAllister, McKinney Not Guilty of Sexual Misconduct: Sergeant Major Convicted of Obstruction, WASH. POST, Mar. 14, 1998, at A1 ("Defense lawyers relied on McKinney's testimony and service record by invoking military rules that allowed the jury to use his outstanding military reputation as grounds for reasonable doubt that he might have committed any of the crimes.").

2. See, e.g., Bob Hohler, Some Say McKinney Verdict Could Have a Chilling Effect, Boston GLOBE, Mar. 15, 1998, at A9 ("McKinney . . . was seen as benefiting from military law that allowed the jury to consider his character and military record as the grounds for finding reasonable doubt of his guilt."); Robert L. Jackson, Jury Clears McKinney of All But 1 of 19 Counts, L.A. TMMES, Mar. 14, 1998, at A1 ("DDefense counsel] Gittins based his defense on McKinney's distinguished 29-year service career and his reputation for character and integrity."); All Things Considered, supra note 1 ("The defense . . . played up McKinney's stellar 29-year record."); Nightline: The Gene McKinney Verdict (ABC television broadcast, Mar. 16, 1998) (quoting Susan Barnes, attorney for one of McKinney's accusers, explaining that "[f]irst of all, you had the good soldier defense, which ... enabled this jury to consider his good service in the military"). 
U.S. armed forces, ${ }^{3}$ raised the profile of the military justice system, a separate criminal and administrative jurisdiction with authority over 1.4 million active-duty servicemembers. ${ }^{4}$ Accused servicemembers, unlike civilian criminal defendants, are permitted to introduce evidence of their "good military character" during the guilt phase of courts-martial. McKinney took full advantage of this military evidentiary doctrine by parading former superiors and subordinates before the court-martial panel to testify about his sterling character and soldierly behavior. ${ }^{6}$ Acquitted on all counts except one charge of obstruction of justice, ${ }^{7}$ McKinney was sentenced to a minor reduction in rank, a sentence that had no impact on his

3. See, e.g., JEAN ZIMMERMAN, TAILSPIN (1995); Lieutenant Commander J. Richard Chema, Arresting 'Tailhook': The Prosecution of Sexual Harassment in the Military, $140 \mathrm{ML}$. L. REv. 1, 1-3 (1993); Bradley Graham \& Tamara Jones, Air Force Averts Trial Of B-52 Pilot: General, Not Honorable, Discharge Granted, WASH. POST, May 23, 1997, at A1 (reporting First Lieutenant Kelly Flinn's resignation over charges of adultery, fraternization, and dishonesty); Bradley Graham \& Fern Shen, Army Suspends More Trainers at Aberdeen: Sex Assault Allegations by Recruits Increase, WASH. POST, Nov. 9, 1996, at A1 (reporting on the Army's investigation of alleged sexual assault by drill sergeants at Aberdeen Proving Grounds); see also Lieutenant Colonel Lawrence J. Morris, In with the Old: Creeping Developments in the Law of Unlawful Command Influence, ARMY LAW., May 1997, at 39, 50 (discussing sexual misconduct by drill sergeants at Aberdeen and elsewhere as it relates to unlawful command influence). The notoriety of McKinney's case did not stop the tide of sex-related scandals in the armed forces. See, e.g., Tresa Baldas \& Steven J. Stark, Navy Tells of New Sex Allegations: Great Lakes Cases Involve Female Recruits, 4 Instructors, CHI. TRIB., May 8, 1998, at 1 (reporting widespread sexual misconduct among Navy instructors).

4. See Office of the Secretary of Defense, Directorate for Info. Operations \& Reports, Statistical Info. Analysis Div., Active Duty Military Strength Report for September 1998 <http://web1.whs.osd.mil/mmid/military/strength.pdf> (visited Dec. 8, 1998) (reporting the total Department of Defense troop strength as $1,406,830$ on September 30,1998). The Uniform Code of Military Justice also applies to reserve personnel, the National Guard, and retired servicemembers. See UNIF. CODE OF MIIITARY JUSTICE, 10 U.S.C. $\$ 802$, art. 2(a)(3) to 2(a)(5) (1994). Although the military has rarely exercised court-martial jurisdiction over retirees, such jurisdiction has been upheld as legitimate. See United States v. Hooper, 26 C.M.R. 417, 419-20, 425 (1958) (upholding the conviction of a rear admiral on charges that were brought nine years into his retirement after Navy investigators spied him engaged in homosexual acts in his own home); Lieutenant Colonel Foote, Courts-Martial of Military Retirees, ARMY LAW., May 1992, at 54 (addressing the limited exercise of court-martial jurisdiction over retirees). But see Richard Sisk, Army General Faces Sex Probe, DAlly NEwS (N.Y.), Mar. 28, 1998, at 12 (reporting the investigation of Army Major General David Hale, who was allowed to retire in April 1998 "despite pending charges that he coerced a junior officer's wife into having sex with him").

5. See infra Part II.

6. See, e.g., Jane Gross, Court-Martial Ends with Talk of Character, N.Y. TMES, Mar. 11, 1998, at A18 (quoting Gittins, McKinney's defense counsel, during closing argument as stating that "[i]n military law, character does count, and character alone may be enough to cause reasonable doubt"); Lisa Hoffman, Jury Gets Sgt. McKinney Case, PLAIN DEALER, Mar. 11, 1998, at 9A ("Three generals, and a host of others who served under or over him, called McKinney a model soldier with the highest of personal and professional standards.").

7. See, e.g., Jury Spares McKinney from Prison, Demotes Him One Rank: Sergeant Major Files Libel Suit Against One Accuser, ST. LOUIS POST-DISPATCH, Mar. 17, 1998, at A1 (reporting that McKinney was sentenced to "be demoted by one pay grade and reprimanded for obstruction of justice"); Bill McAllister, Jury Cuts McKinney's Rank, Pay: Ex-Top Sergeant Is Spared Jail Term, WASH. POST, Mar. 17, 1998, at A1 (detailing the verdict in McKinney's court-martial that cleared him of 18 charges of sexual misconduct against six women while convicting him of a single count of obstruction of justice). 
military pay and benefits in retirement. ${ }^{8}$ A commonly used and frequently effective defense tactic at courts-martial, ${ }^{9}$ the defense that worked so well for McKinney has disturbing implications for the roles of rank, gender, and race in military justice.

The broad availability of the good soldier defense is supported by many legal doctrines and policy arguments, but none withstand close analysis. Cloaked in the mantle of longstanding court-martial tradition, justified by doctrines of questionable salience, and preserved by judges resistant to the Military Rules of Evidence's limitations on character evidence, the good soldier defense advances the perception that one of the privileges of high rank and long service is immunity from conviction at court-martial. The defense privileges a certain type of accused servicemember-a person of high rank and reputation in the military community-at the expense of the overall fairness of the court-martial system. By permitting the introduction of good military character evidence during the guilt phase of a courtmartial, the good soldier defense encourages factfinders to focus on the reputation of accused individuals rather than on their alleged criminal acts. In a system already marked by extraordinary discretion, from a commander's decision about whether and how to bring criminal charges to the separate sentencing phase of trial ${ }^{10}$ the good soldier defense undercuts the military justice system's commitment to an objective trial process by adding an element of subjectivity to the merits phase of a court-martial.

In order to analyze the good soldier defense, Part II begins with a description of the defense, examining both the evidentiary doctrine that permits liberal admission of "good military character" evidence at courtsmartial and the comparable civilian doctrine and practice. Part III reviews and critiques the legal and public policy justifications for the good soldier defense, Part IV discusses the shifting definitions of a "good soldier," and Part V explores the good soldier defense in practice. Finally, Part VI highlights the disparate benefits of the good soldier defense, revealing how

8. McKinney's sentence to forfeit retirement pay could not be implemented because of a 1986 law enacted to protect the senior enlisted member of each service from losing benefits if removed from the top enlisted post. The law prohibits the imposition of any retirement penalty on a person who has served in the top enlisted post if that person leaves for a lesser-paying military job, regardless of the reason for his departure. See Military Retirement Reform Act, 10 U.S.C. $\$ 1406$ (i) (1994). McKinney's single conviction effectively ended his military career, but it did not reduce his retirement pay. See Ex-Top GI To Get Full Benefits, NEwSDAY (N.Y.), May 13, 1998, at A23; McKinney To Get Full Retirement Pay Despite Conviction, CHI. TRIB., May 12, 1998 , at 6.

9. See, e.g., Major Lang \& Major Henley, The Cost of Presenting "Good Soldier" Evidence: Testing the Foundation of Character Testimony on Cross-Examination, ARMY LAW., Oct. 1996, at 21, 21 ("The defense [counsel during courts-martial] will often present a 'good soldier' defense by offering evidence of the accused's military service. This evidence can, if effectively presented, be extremely persuasive.").

10. See infra note 12 (describing the bifurcated nature of courts-martial). 
servicemembers of high rank can escape censure by bringing character rather than facts to center stage at courts-martial.

\section{THE “GOOD SOLDIER" DEFENSE}

\section{A. Military Rule of Evidence 404(a)(I)}

The "good soldier" defense refers to an accused servicemember's introduction of evidence of good military character in order to convince a military judge or jury that the accused did not commit the offense charged. ${ }^{11}$ In addition to the implicit use of character evidence at the beginning of the investigative process, when a commander must decide whether to bring charges, and its explicit use at the end of trial, when a court-martial must determine an appropriate sentence, ${ }^{12}$ generic good character evidence is admitted on the merits under Military Rule of Evidence 404(a)(1):

(a) Character evidence generally. Evidence of a person's character or a trait of a person's character is not admissible for the purpose of proving that the person acted in conformity therewith on a particular occasion, except:

(1) Character of the accused. Evidence of a pertinent trait of the character of the accused offered by an accused, or by the prosecution to rebut the same. ${ }^{13}$

Intended to limit the circumstantial use of character evidence, ${ }^{14}$ Rule 404(a)(1) makes an exception for "evidence of a pertinent trait." 15 In courts-martial, the 404(a)(1) exception has been interpreted to permit evidence of general "good military character," as well as proof of pertinent character traits, to be admitted on the merits. ${ }^{16}$ Evidence admitted under the

11. See, e.g., Lieutenant Colonel Paul A. Capofari, Military Rule of Evidence 404 and Good Military Character, 130 MLL. L. REv. 171, 171-72 (1990); see also 1 MCCORMICK, EVIDENCE $\S 191$ (John William Strong ed., 4th ed. 1992). A court-martial may be either a military judge or a panel of servicemembers. An accused may waive the right to trial by members and request trial by military judge alone. See RULES FOR COURTS-MARTIAL, 903(b)(2), 903(c)(2). In capital cases, such bench trials are not permitted. See id. at 201(f)(1)(C).

12. In this Note, I address only admissibility during findings. I do not address the separate question of admissibility during sentencing. Courts-martial, unlike noncapital civilian criminal trials, are bifurcated; an adversarial sentencing hearing follows a conviction on the merits, and the court-martial panel, not the military judge, determines the sentence. See, e.g., 2 FRANCIS A. GILLIGAN \& FREDRIC I. LEDERER, COURT-MARTIAL PROCEDURE 2-3 (1991).

13. MIL. R. EVID. 404(a)(1).

14. See MIL. R. EVID. 404(a)(1) cmt. MANUAL for COURTS-MARTIAL, UNITED STATES app. at A22-34 (1995).

15. MIL. R. EVID. 404(a)(1).

16. See Mul. R. Evid. 404(a)(1) cmt. MANUAL FOR COURTS-MARTIAL app. at A22-34 (1995); EDWARD M. BYRNE, MHITARY LAW 369 (3rd ed. 1981). 
exception "is aimed at creating the inference that because the accused is a person of good character and people of good character do not commit crimes, the accused must not have committed the crimes charged." 17 Such good character evidence may raise sufficient doubt about the accused's guilt in the minds of factfinders to prevent a criminal conviction. ${ }^{18}$

\section{B. Character Defenses in Civilian Criminal Trials}

The good soldier defense exists only in courts-martial; an accused civilian cannot be a "good soldier." Accordingly, even though Federal Rule of Evidence 404(a)(1) is identical to Military Rule of Evidence 404(a)(1), the admissibility of character evidence in courts-martial differs from evidentiary practice in civilian trials. In both courts-martial and civilian trials, the defendant may introduce "pertinent" character evidence that may, by itself, create a reasonable doubt as to the accused's guilt. ${ }^{19}$ However, only at courts-martial may evidence of "good military character" be admitted under the 404(a)(1) exception. ${ }^{20}$

Despite this difference in the content of military and civilian character evidence, the use of character evidence in both civilian trials and courtsmartial is limited by a strong presumption against propensity evidence. Propensity evidence is evidence offered to prove that because a defendant tended to act a certain way in the past, he probably acted that way in committing, or not committing, an alleged crime. The limits on propensity evidence prevent a prosecutor from using evidence of the defendant's bad character to win a conviction and restrict a defendant's ability to use good character to win acquittal. ${ }^{21}$ Some scholars have argued that character

17. Capofari, supra note 11 , at 172 .

18. The standard of proof at court-martial is the same as in a civilian criminal trial; proof beyond a reasonable doubt is required for conviction. See, e.g., GILLIGAN \& LEDERER, supra note 12 , at 869.

19. See Michelson v. United States, 335 U.S. 469, 471-72 (1948); Joan L. Larsen, Comment, Of Propensity, Prejudice, and Plain Meaning: The Accused's Use of Exculpatory Specific Acts Evidence and the Need To Amend Rule 404(b), 87 Nw. U. L. REV. 651, 691 (1993) (noting "the firmly established rule allowing the accused to introduce evidence of his good character as part of his defense").

20. See FED. R. EVID. 404(a)(1) advisory committee's note; see also CHRISTOPHER B. MUEller \& LAIRD C. KIRKPATRICK, FEDERAL EvidENCE 536-37, 548-54 (2d ed. 1994) (noting that the advisory committee added the term "pertinent trait" to Rule 404(a)(1) in order "to require or at least encourage greater specificity in proving character"). But cf. STEPHEN A. SALTZBURG ET AL., MILITARY RULes of EVIDENCE MANUAL 523 (4th ed. 1997) ("Although the military provision is broader than its federal counterpart, the two Rules have produced similar results."). The precise amount and type of character evidence admitted in federal criminal trials is not my primary concem; I simply wish to highlight the distinction between civilian and military evidentiary practices.

21. See, e.g., Edward J. Imwinkelried, Uncharged Misconduct, CRIM. JUST., Summer 1986, 6, at 7-8; David J. Kaloyanides, Note, The Depraved Sexual Instinct Theory: An Example of the Propensity for Aberrant Application of Federal Rule of Evidence 404(b), 25 LOY. L.A. L. REV. 
evidence is probative in determining the guilt of an accused. ${ }^{22}$ Nonetheless, American jurisprudence has rejected the premise that a defendant's bad or good character can serve as an acceptable basis for conviction or acquittal. ${ }^{23}$ Proof of guilt in a criminal trial depends on establishing that a defendant committed the charged offense, not that the accused is a bad person and thus likely to have committed a crime. ${ }^{24}$ Permitting an accused to use her good character as a defense poses less risk of injustice than allowing prosecutors to introduce bad character evidence, but the criminal law's emphasis on punishing acts rather than status ${ }^{25}$ limits both practices. ${ }^{26}$

1297, 1299 (1992) ("The prohibition against character propensity evidence has a long history in Anglo-American jurisprudence.").

22. See Benjamin B. Sendor, The Relevance of Conduct and Character to Guilt and Punishment, 10 NOTRE DAME J.L. ETHICS \& PUB. POL'Y 99, 99-100 (1996) (describing the "character theorists" who deem character a criterion of guilt as well as an indicator of appropriate punishment); see also David Crump, How Should We Treat Character Evidence Offered To Prove Conduct?, 58 U. COLO. L. REV. 279, 283 (1987) (arguing for jurors' ability to analyze character evidence); H. Richard Uviller, Evidence of Character To Prove Conduct: Illusion, Illogic, and Injustice in the Courtroom, 130 U. PA. L. REV. 845 (1982) (arguing for the admissibility of character evidence).

23. See Major Stephen R. Henley, Caveat Criminale: The Impact of the New Military Rules of Evidence in Sexual Offense and Child Molestation Cases, ARMY LAW., Mar. 1996, at 82, 86 ("American jurisprudence is grounded in the theory that courts try cases rather than persons."); Sendor, supra note 22, at 136. See generally Thomas J. Reed, The Development of the Propensity Rule in Federal Criminal Causes 1840-1975, 51 U. CIN. L. REV. 299 (1982) (discussing the evolution of the propensity rule prior to the Federal Rules of Evidence's enactment); L. Kinvin Wroth, The Federal Rules of Evidence in the States: A Ten-Year Perspective, 30 VILL. L. REV. $1315,1329-30$ (1985) (describing prohibitions on character evidence under state rules).

24. See, e.g., MCCORMICK, supra note 11, at 786-93 (discussing the rejection of propensity evidence); David P. Leonard, In Defense of the Character Evidence Prohibition: Foundations of the Rule Against Trial by Character, 73 IND. L.J. 1161 (1998) (stating the moral, historical, and philosophical arguments in favor of preserving the ban on character evidence). Of course, limiting evidence of propensity does not prevent jurors and judges from drawing conclusions based on evidence of character, despite its questionable predictive value. See, e.g., Edward J. Imwinkelried, The Use of Evidence of an Accused's Uncharged Misconduct To Prove Mens Rea: The Doctrines That Threaten To Engulf the Character Evidence Prohibition, 130 MIL. L. REv. 41, 47-48 (1990) (stating that jurors judge guilt based on character); Miguel Angel Mendez, California's New Law on Character Evidence: Evidence Code Section 352 and the Impact of Recent Psychological Studies, 31 UCLA L. REV. 1003, 1050-59 (1984) (describing the weak predictive value of propensity evidence); Ronald R. Boyce, Evidence of Other Crimes or Wrongdoing, UTAH B.J., Summer 1977, at 31 .

25. Punishing an accused for bad character also risks violating the constitutional ban on criminalizing status rather than conduct. See Robinson v. California, 370 U.S. 660, 666-67 (1962) (holding that the Eighth Amendment's ban on cruel and unusual punishment bars prosecution for a mere status, such as that of being a drug addict); see also MODEL PENAL CODE $\$ 2.01$ (requiring that a criminal act involve some type of conduct); Robert C. Ellickson, Controlling Chronic Misconduct in City Spaces: Of Panhandlers, Skid Rows, and Public-Space Zoning, 105 YALE L.J. 1165 , 1242-43 (1996) (describing the constitutional ban on status crimes); Mark Kelman, Interpretive Construction in the Substantive Criminal Law, 33 STAN. L. REV. 591 (1981) (arguing against the possibility of status crimes under the Constitution). Of course, military law and policy already punish at least one status-that of being gay. See, e.g., Janet E. Halley, The Status/Conduct Distinction in the 1993 Revisions to Military Anti-Gay Policy, 3 GLQ: J. LESBIAN \& GAY STUD. 159 (1996).

26. See, e.g., MCCORMCK, supra note 11, at 786-93; PAUL F. ROTHSTEIN ET AL., EVIDENCE: CASES, MATERIALs, AND PROBlems 285-310 (2d ed. 1998); Joshua Dressler, Reflections on Excusing Wrongdoers: Moral Theory, New Excuses, and the Model Penal Code, 19 RUTGERS L.J. 
Civilian judges respect both sides of the propensity doctrine by restraining prosecutors from introducing character evidence to prove that a defendant acted "in conformity therewith" 27 in committing the alleged crime and by allowing defendants to introduce only evidence of specific traits, such as truthfulness or law-abidingness, rather than evidence of general good character. ${ }^{28}$

\section{Character Defenses in Courts-Martial}

Unlike civilian criminal defendants, accused servicemembers may almost always get evidence of their good military character admitted at court-martial, subject to the ruling of the military judge. Courts-martial have stretched the exception to allow more liberal use of character evidence than is generally permitted in civilian courts. ${ }^{29}$ In addition, the Military Rules are applied at the discretion of judges, and reversal of evidentiary decisions by appellate courts is the exception rather than the rule. ${ }^{30}$ Military judges routinely admit generic good character evidence under the broad category of evidence of "good military character" that would not be admitted at a civilian trial.

671, 697-99 (1988) (explaining the moral problem of excusing wrongdoers based on evidence of character rather than conduct); Sendor, supra note 22, at 123.

27. FED. R. EVID. 404(a).

28. See, e.g., United States v. Angelini, 678 F.2d 380, 382 (1st Cir. 1982) (upholding the admission of evidence about a defendant's law-abiding nature as a pertinent trait). Of course, Article III civilian judges apply the rules of evidence with perhaps even greater discretion than military judges. See, e.g., United States v. Hewitt, 634 F.2d 277 (5th Cir. Unit A Jan. 1981) (upholding the admission of evidence of general good character as pertinent); Fred Warren Bennett, Is the Witness Believable? A New Look at Truth and Veracity Character Evidence and Bad Acts Relevant to Truthfulness in a Criminal Case, 9 ST. THOMAS L. REV. 569, 579 (1997) ("Whether courts strictly adhere to [FED. R. EVID. 404(a)(1)] is an open question."); David P. Leonard, The Use of Character To Prove Conduct: Rationality and Catharsis in the Law of Evidence, 58 U. CoLO. L. REV. 1, 16 (1986) (analyzing the reasons why litigants seek to admit character evidence); Thomas J. Reed, The Character Evidence Defense: Acquittal Based on Good Character, 45 CLEV. ST. L. REv. 345 (1997) (analyzing the successful good moral character defense employed in United States v. Martinez, 924 F. Supp. 1025 (D. Or. 1996)).

29. See Major Lawrence J. Morris, Keystones of the Military Justice System: A Primer for Chiefs of Justice, ARMY LAW., Oct. 1994, at 15, 22 (noting that the highest military court "ruled that a 'good soldier' defense could be presented in any case"). Because the admission of character evidence occurs at the discretion of the trial judge, generalizing about evidentiary practices at courts-martial is difficult. However, broad trends in judicial decisions concerning the admissibility of character evidence are discernible in appellate records and military-legal scholarship.

30. The standard for review of evidentiary decisions is abuse of discretion. See, e.g., United States v. Nash, 44 M.J. 456, 457 (C.A.A.F. 1996) (holding that the decision to admit or exclude evidence is reviewed for abuse of discretion); Eugene R. Fidell, Going on Fifty: Evolution and Devolution in Military Justice, 32 WAKE FOREST L. REv. 1213, 1223 (detailing the military case law for appellate standards of review of evidentiary decisions). See generally David P. Leonard, Appellate Review of Evidentiary Rulings, 70 N.C. L. REv. 1155 (1992) (assessing the scope of authority granted to trial judges under the Federal Rules of Evidence); Scott J. Shapiro, Note, Reviewing the Unreviewable Judge: Federal Prosecution Appeals of Mid-Trial Evidentiary Rulings, 99 YALE L.J. 905 (1990) (advocating more meaningful appellate review of evidentiary rulings). 
This difference in evidentiary practice is partly due to the distinctive objectives of the military justice system. A court-martial resembles a civilian criminal trial in many respects, but "military due process" carries different protections than the civilian due process guaranteed under the Fifth and Fourteenth Amendments. ${ }^{31}$ Courts-martial are part of a disciplinary scheme relied upon to maintain good order among troops, to preserve the obedience and conformity deemed necessary to successful military action, and to eliminate from the military those individuals who pose a risk to other servicemembers or to national security itself. ${ }^{32}$ Because of the special objectives of military justice, active duty military officers, not an independent Article III judiciary, preside over courts-martial. ${ }^{33}$ Servicernembers are chosen to serve as jurors by a commanding officer, not by a random or arbitrary selection process, ${ }^{24}$ and a broader variety of acts are deemed criminal under military law than under civilian criminal codes. ${ }^{35}$

The good soldier defense takes advantage of this special military context by emphasizing an accused's loyalty to the armed forces and past military performance. The defense counters evidence of wrongdoing with proof that an accused has been a "good soldier" during her military career. Prior to 1980, no codified rules governed the admission of evidence at courts-martial, but standard practice called for military judges to admit good military character evidence broadly ${ }^{36}$ After the Military Rules of Evidence were adopted in 1980, judicial interpretations of Rule 404(a)(1) preserved this traditional military defense by defining the limiting term

31. See United States v. Clay, 1 C.M.R. 74, 77 (C.M.A. 1951) (holding that the rights granted to accused servicemembers are based not on the Constitution but on "the laws as enacted by Congress").

32. See William Winthrop, Miltary Law and PRECEDents 45-56 (2d ed. 1920) (tracing the history of the court-martial); see also Sam Nunn, The Fundamental Principles of the Supreme Court's Jurisprudence in Military Cases, 29 WAKE FOREST L. REV. 557, 557-66 (1994) (explaining why military justice is necessarily different from civilian justice).

33. See 10 U.S.C. § 826 (1994).

34. See id. $\$ 825$.

35. See id. $\$ \S 933,934$ (criminalizing inter alia, being absent without leave (AWOL) and "conduct unbecoming an officer and a gentleman").

36. See United States v. Vandelinder, 20 M.J. 41, 45-46 (C.M.A. 1985); WINTHROP, supra note 32, at 320, 350-52; Capofari, supra note 11, at 172-74 (1990); see also United States v. Clemons, 16 M.J. 44, 47 (C.M.A. 1983) (Everett, C.J., concurring) (explaining the limited change in evidentiary procedure that accompanied the adoption of the Military Rules of Evidence). 
"pertinent" as merely "relevant," ${ }^{37}$ allowing the liberal admissibility of military character evidence to continue. ${ }^{38}$

The good soldier defense is broadly available and frequently used at courts-martial..$^{39}$ Although official guidance on Rule 404(a)(1) limits the introduction of "evidence of good military character" to those instances "when that specific trait is pertinent," ${ }^{40}$ military courts have deemed military character pertinent to every category of criminal offense. ${ }^{41}$ For an accused servicemember, the good soldier defense has many advantages. It is simple, ${ }^{42}$ easy to mount, ${ }^{43}$ and almost universally applicable. ${ }^{44}$ Nearly every servicemember can introduce good military character evidence, as officers and enlisted personnel receive periodic performance evaluations as a matter of routine, providing extensive documentary evidence of good

37. Clemons, 16 M.J. at 47 ("The word 'pertinent' is read as synonymous with 'relevant." (internal citations omitted)); see also United States v. Elliott, 23 M.J. I, 5 (C.M.A. 1986) (discussing the admissibility of evidence of a "pertinent trait" of the accused); United States v. Stanley, 15 M.J. 949, 951-52 (A.F.C.M.R. 1983) (same). See generally FED. R. EVID. 401 ("'Relevant evidence' means evidence having any tendency to make the existence of any fact that is of consequence to the determination of the action more probable or less probable than it would be without the evidence."); MIL. R. EVID. 401 (same).

38. See United States v. Gleason, 43 M.J. 69, 75 n.11 (C.A.A.F. 1994) ("Consistent with the traditional military emphasis on the importance of good character, Mil.R.Evid. 404(a)(1) has been liberally construed to permit evidence of an accused's general 'good character."').

39. My understanding of the use of the good soldier defense at courts-martial has been enhanced through conversations with several attorneys experienced in the practice of military law. Telephone Interview with William D.S. Dixon, former Chief Judge, Air Force Court of Criminal Appeals, now Staff Counsel, Central Legal Staff, U.S. Court of Appeals for the Armed Forces (Aug. 24, 1998); Interview with Eugene R. Fidell, former Coast Guard officer, now President, National Institute for Military Justice, in New Haven, Conn. (Mar. 30, 1998); Telephone Interview with Lieutenant Colonel Monty Forrester, formerly part of the defense counsel team for Gene McKinney, now Executive Officer, Headquarters, U.S. Army, Trial Defense Service (Aug. 31, 1998); Telephone Interview with Lieutenant Colonel Frederick Kennedy, former military judge, now Associate Professor, Department of Law, U.S. Military Academy (Oct. 7, 1998); Telephone Interview with Robert C. Mueller, former Army Judge Advocate, now Senior Commissioner, U.S. Court of Appeals for the Armed Forces (Nov. 18, 1998); Telephone Interview with Stephen D. Smith, former Chief, Defense Appellate Division, U.S. Army Legal Services Agency, now Staff Counsel, Central Legal Staff, U.S. Court of Appeals for the Armed Forces (Aug. 24, 1998). These attorneys spoke for themselves, not for their organizations or branches of service. All agreed on the general outlines of the good soldier defense, but they differed somewhat on its significance as a defense tactic. Few share my dim view of the advisability of the good soldier defense. See infra notes 110-111, 119, 123, 142, 144, 151 (citing individual interviews).

40. MIL. R. EVID. 404(a)(1), cmt. MANUAL FOR Courts-MARTIAL app. at A22-34.

41. See, e.g., Morris, supra note 29 , at 22 (noting that the highest military court "ruled that a 'good soldier' defense could be presented in any case"); see also SALTZBURG, supra note 20, at 523-568 (explaining the broad applicability of the good soldier defense).

42. Part of the popularity of the good soldier defense is its intuitive simplicity, since it plays on the court-martial members' desire to know more about defendants in order to determine whether they are likely to have committed the charged offenses.

43. See, e.g., Captain Andrea, Expanding the Good Soldier Defense: Use of Character Evidence as a Defense at Trial, ARMY LAw., Dec. 1993, at 30, 31.

44. See Robinson O. Everett, Military Rules of Evidence Symposium: An Introduction, 130 MIL. L. REV. 1, 3 (1990) ("[A]n accused's general military character is admissible in almost any conceivable trial by court-martial."). 
character to supplement the affidavits and live testimony of military colleagues and commanders. ${ }^{45}$ Using evidence of "good military character" to defend an accused is thus a feature common to many courts-martial. ${ }^{46}$

\section{CRITIQUING THE USE OF “MitTARy Character”}

This Part outlines and critiques various justifications for the broad admissibility of good military character evidence. After explaining the rationale behind the military's separate criminal law, I contrast the justification for the admission of "good soldier" evidence advocated by a noted scholar of evidence law, John Henry Wigmore, with the explanation offered by the most-cited authority on military law, Colonel William Winthrop. ${ }^{47}$ The logical and functional limitations of the various justifications for the good soldier defense cast doubt on the doctrine behind the good soldier defense.

\section{A. "A Separate Society": Courts-Martial and the Constitution}

The evidentiary rules and criminal procedure applied in courts-martial are part of the military justice system, a constitutionally distinct body of law and procedure that co-exists with Article III courts. "Military due process" describes pretrial military investigations and court-martial procedure, in contrast to the mandates of due process applied at civilian criminal investigations and trials. ${ }^{49}$ The due process and other constitutional

45. MIL. R. EVID. 405 governs the form of admissible character evidence.

46. See infra Part V.

47. Winthrop, a practicing attorney prior to his Civil War-era service in the United States Army, taught law at West Point and served as Assistant Judge Advocate General of the Army. His treatise, first published in 1886, remains the most frequently cited authority on military law. See Igor I. Kavass \& Adolf Sprudzs, Editorial Introduction to WILLIAM WINTHROP, MIITARY LAW AND PRECEDENTS (Igor I. Kavass \& Adolf Sprudzs eds., William S. Hein \& Co., 1979) (1920).

48. The constitutional underpinnings of the military justice system are threefold: first, the power of Congress to declare war, raise armies, regulate land and naval forces, and discipline militias; second, the executive's power to command the armed forces, commission officers, and execute the laws; and third, the Fifth Amendment's exception to the requirement of a grand jury indictment for those "in actual service in a time of war or public danger." See U.S. CoNST. art. I, \$ 8; id. at art. II, \$\$ 1-3; id. at amend. V; see also WINTHROP, supra note 32, at 15-16 (explaining the constitutional origins of military law). The military justice system is thus constitutionally derived and subject to only limited scrutiny from Article III courts. Civilian courts' deference to the military's rules, regulations, and judgment has varied historically, depending on the political climate and legal issues involved, but the judiciary has consistently respected the legitinacy of courts-martial and administrative justice in the armed forces.

49. See U.S. Const. amend. V; Middendorf v. Henry, 425 U.S. 25, 43 (1976); Burns v. Wilson, 346 U.S. 137, 140 (1953); Reaves v. Ainsworth, 219 U.S. 296, 304 (1911) ("To those in the military or naval service of the United States the military law is due process."); Dynes v. Hoover, 61 U.S. 65, 81-82 (1857). 
rights of servicemembers have been the subject of considerable debate. ${ }^{50}$ The procedures of the military criminal justice system are considered legitimate under prevailing constitutional interpretations. ${ }^{51}$

Servicemembers' rights are limited by their status as soldiers, particularly since the Supreme Court's adoption of an extremely deferential standard of review toward the military. ${ }^{52}$ Despite this deference, the procedural rights of soldiers have evolved over the last century and a half alongside reform in civilian criminal procedure. ${ }^{53}$ Still, the military justice system has its ardent critics, ${ }^{54}$ who reject military law as overly vague, ${ }^{55}$ discriminatory ${ }^{56}$ and apt to abuse of discretion by commanders. ${ }^{57}$

Defenders of military justice have responded to such criticism by emphasizing the "separate society" of military service and the importance

50. See, e.g., Gordon D. Henderson, Courts-Martial and the Constitution: The Original Understanding, 71 HARV. L. REV. 293, 303-24 (1957) (analyzing the original intent of the Framers to apply the Fifth and Sixth Amendments to the military justice system and concluding that the Bill of Rights protects servicemembers as well as civilians); Earl Warren, The Bill of Rights and the Military, 37 N.Y.U. L. REv. 181, 183, 188, 193 (1962) (advocating "the principle of separation and subordination of the military establishment from, and its subordination to, civil authority" and arguing that "our citizens in uniform may not be stripped of basic rights simply because they have doffed their civilian clothes" and that, in most peacetime cases, "a capitulation to the claim of military necessity would be a needless sacrifice").

51. See, e.g., Solorio v. United States, 483 U.S. 435 (1987).

52. See Rostker v. Goldberg, 453 U.S. 57, 64-72 (1981) (discussing the need for extreme deference to the armed forces' personnel decisions).

53. See generally JOSEPH W. BISHOP, JR., JUSTICE UNDER FIRE: A STUDY OF MILITARY LAW (1974); WILlIAM T. GENEROUS, JR., SWORDS AND SCALES: THE DEVELOPMENT OF THE UNIFORM CODE OF MIIITARY JUSTICE (1973) (sketching the development and reform of military law from World War II through the Military Justice Act of 1968); JONATHAN LURIE, ARMING MILITARY JUSTICE: THE ORIGINS OF THE UNITED STATES COURT OF MIITAARY APPEALS, 17751950 (1992) (tracing the reforms that led to the establishment of a military appeals court composed of civilian judges); Walter T. Cox III, The Army, the Courts, and the Constitution: The Evolution of Military Justice, 118 MIL. L. REV. 1 (1987).

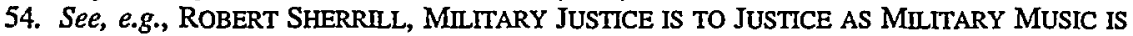
To Music (1970); Keith M. Harrison, Be All You Can Be (Without the Protection of the Constitution), 8 HARV. BLACKLETTER J. 221 (1991); Michael I. Spak, Military Justice: The Oxymoron of the 1980's, 20 CAL. W. L. REV. 436 (1984).

55. See, e.g., James A. Hagan, The General Article-Elemental Confusion, $10 \mathrm{Mn}$. L. REv. 63 (1960) (describing the changing interpretations of Article 134); Edward F. Sherman, The Civilianization of Military Law, 22 ME. L. REV. 3 (1970) (advocating the abolishment of the general articles as antiquated relics); Comment, The Discredit Clause of the UCMJ: An Unrestricted Anachronism, 18 UCLA L. REV. 821 (1971) (noting that the discredit clause of Article 134 is more unconstitutionally vague than the rest of the article). But see Frederick Bernays Wiener, Are the General Military Articles Unconstitutionally Vague?, 54 A.B.A. J. 357, 362-64 (1968) (arguing that the general articles enhance the flexibility of military law and enable the enforcement of a "higher code termed honor").

56. See, e.g., Michelle M. Benecke \& Kirstin S. Dodge, Military Women in Nontraditional Fields: Casualties of the Armed Forces' War on Homosexuals, 13 HARV. WOMEN's L.J. 215 (1990); Halley, supra note 25.

57. See LUTHER C. WeSt, They CALl IT JUSTICE: COMMAND INFLueNCE AND THE COURTMARTLAL SYSTEM 15-27 (1977) (detailing the pernicious effects of commanders' influence on military lawyers and courts-martial outcomes). 
of enforcing discipline among servicemembers, particularly during war. ${ }^{58}$ This argument about the uniqueness of military life, and the resulting need for a special system of criminal procedure, is frequently cited in support of the current practice of admitting good military character evidence during findings. ${ }^{59}$ Although some servicemembers-those on-board deployed ships, or those stationed at remote outposts-live and work in environments isolated from civilian life, casting the entire American military, a postmodern force of scattered troops, complex missions, and gender and racial diversity, as wholly "separate" from civilian communities overstates the case. ${ }^{60}$ But, even conceding the unique nature of military discipline and the need for a separate legal system, no compelling rationale exists for a judicial interpretation of character admissibility so at odds with federal rules and civilian evidentiary practice. ${ }^{61}$ If a separate military society does still exist, its circumstances and the servicemembers who are subject to its constraints are not so remote from modern civil society as to justify such a dramatically different rule. ${ }^{62}$

\section{B. The Soldier Under Surveillance: Dean Wigmore}

In arguing for the liberal admissibility of "good military character" evidence, military lawyers and judges have not relied solely on arguments about the military as a "separate society" or a legal world unto itself. Part

58. See Frank E. Barker, Military Law-A Separate System of Jurisprudence, 36 U. CIN. L. REV. 223 (1967) (exploring aspects of military jurisdiction); James M. Hirschhom, The Separate Community: Military Uniqueness and Servicemen's Constitutional Rights, 62 N.C. L. REV. 177 (1984) (detailing the rationales and critiques of the "separate community" doctrine).

59. See, e.g., United States v. Kahakauwila, 19 M.J. 60, 61 (C.M.A. 1984) ("[T]he peculiar nature of the military community makes similar interpretation [of Rule 404(a)(1)] inappropriate. Unlike his civilian counterpart, the conduct of a military person is closely observed both on and off duty, and such observation provides the material upon which performance reports and other evaluations are based.").

60. See, e.g., Hirschhorn, supra note 58, at 207 ("The separate community doctrine, then, has been criticized as being based on a notion of military life that is not consistent with present reality and on claims of necessity that are hardly articulated, much less demonstrated."); see also Karen A. Ruzic, Note, Military Justice and the Supreme Court's Outdated Standard of Deference: Weiss v. United States, 70 CHI.-KENT. L. REV. 265, 265-66 (1994) (arguing that the modern military is like a large civilian corporation and "does not differ greatly from civilian society," making the "rationale for a high degree of deference obsolete").

61. See United States v. Ezell, 6 M.J. 307, 313 (C.M.A. 1979) ("When a party urges that a different rule obtains in the military than in the civilian sector, the burden is upon that party to show the need for such a variation."); Courtney v. Williams, 1 M.J. 267, 270 (C.M.A. 1976) ("[T] he burden of showing that military conditions require a different rule than that prevailing in the civilian community is upon the party arguing for a different rule.").

62. See, e.g., Louis Ephriam Hicks, The Effect of Technology on Social Control in U.S. Military Organizations: Trends in Court-Martial Rates from 1917-1991 (1994) (unpublished Ph.D. dissertation, University of Maryland) (on file with author) (positing "that technological complexity has increased and diffused uncertainty in U.S. military organizations," leading military institutions to modify "their compliance structures, emphasizing persuasion in place of coercion") (quotations from unpaginated abstract). 
of the "civilianization" of military law in recent years has involved the increased consideration and citation of experts in civilian law and procedure, particularly those with military experience. Dean Wigmore, a noted legal scholar who was appointed a major in the Army's Judge Advocate General Corps during World War I, ${ }^{63}$ has been a favorite source of scholarly support for the military judges who have expanded the 404(a)(1) exception for character evidence into its current form. ${ }^{64}$

A closer look at Wigmore's frequently cited discussion reveals that his analysis does not support the current use of the good soldier defense. The key passage in his work about good character in the military is excerpted below, with emphasis added to the lines extracted and quoted most often in judicial opinions:

A certificate of honorable discharge from the United States Army or Navy... should be liberally construed, i.e., as importing not merely general good character, or the specific traits mentioned, but any other of the fundamental moral traits that may be relevant in criminal cases. The soldier is in an environment where all weaknesses or excesses have an opportunity to betray themselves. $\mathrm{He}$ is carefully observed by his superiors-more carefully than falls to the lot of any member of the ordinary civil community; and all his delinquencies and merits are recorded systematically from time to time on his "service record," which follows him throughout his army career and serves as the basis for the terms of his final discharge. The certificate of discharge, therefore, is virtually a summary of his entire service conduct, both as a man and as a soldier. ${ }^{65}$

There are three separate problems of interpretation in the military judiciary's reliance on the italicized sections of the above quotation to rationalize the good soldier defense. First, contrary to the assertions about this passage in military appellate opinions, ${ }^{66}$ Wigmore is writing about the admission of military records in civilian criminal trials, not in support of character evidence at court-martial. ${ }^{67}$ His suggestion that discharge

63. Wigmore was immediately put to work drafting military-related law. See Soldiers' and Sailors' Civil Rights Bill: Hearings on S. 2859 Before the Subcomm. of the Senate Comm. on the Judiciary, 65th Cong., 13-14 (1917) (statement of John H. Wigmore, Major, Judge Advocate Officers' Reserve Corps).

64. See, e.g., United States v. Clemons, 16 M.J. 44, 48 (C.M.A. 1983); United States v. Craddolph, 36 C.M.R. 688, 690 (A.B.R. 1966); United States v. Browning, 5 C.M.R. 27, 29 (C.M.A. 1952).

65. JOHN HENRY WIGMORE, A TREATISE ON THE ANGLO-AMERICAN SYSTEM OF EVIDENCE IN TRIALS AT COMMON LAW $\S 59$, at $462-63$ (3d ed. 1940) (third emphasis added); see, e.g., Clemons, 16 M.J. 48 (quoting WIGMORE, supra).

66. See supra note 64 .

67. See WIGMORE, supra note $65, \S 59$. Because Wigmore's analysis concerns admissibility in civilian trials, where the special objectives and procedural distinctiveness of military justice are 
certificates be admitted at criminal trials has not been followed by civilian tribunals; military discharge records have been rejected as irrelevant by most civilian courts. ${ }^{68}$ Second, Wigmore assigns special value to the discharge certificate as "a summary of [a servicemember's] entire service conduct." A comprehensive service record is not the type of evidence generally admitted at courts-martial. Rather, live testimony of peers and supervisors, and occasionally short-term evaluative documents, are most commonly introduced as proof of character. Third, Wigmore did not mention "good military character" as a separate trait in any of his discussions of courts-martial and character evidence. Each of these interpretive factors is obscured by military judges' tendency to excerpt only the italicized part of the above quotation in support of the good soldier defense.

There are contextual, as well as textual, problems with the military judiciary's application of Wigmore. Wigmore based his rationale on two distinctive aspects of military life that do not withstand close scrutiny: (1) an "environment" that betrays all weaknesses; and (2) the careful observation of soldiers practiced by military superiors. Wigmore's military "environment" refers not to modern-day military life, but to military service in times of war-and not simply any war, but World War I, the purported "War to End All Wars." ${ }^{69}$ It is debatable whether World War I was the crucible of good character that Wigmore envisioned and whether combat reveals the moral worth of individuals, but even a casual observer cannot deny the profound differences between the American Expeditionary Force of 1917 and today's military. Servicemembers are deployed on peacekeeping and peacemaking ventures around the world, ${ }^{70}$ work within a diverse force of multiple races and genders, ${ }^{71}$ and live amid civilians near

absent, his assertions do not support an evidentiary doctrine that is applicable only in courtsmartial.

68. See State v. Oliviera, 534 A.2d 867, 868-69 (R.I. 1987) (holding that the trial court did not err in refusing to admit the defendant's military record as evidence in a trial for sexual assault and child molestation); see also 1A JOHN HENRY WIGMORE, EVIDENCE IN TRIALS AT COMMON LAW $\S 59$, at 1252 n.7 (Peter Tillers ed., 1983) (listing cases in which an accused's service record was not admissible as character evidence).

69. See, e.g., Allan R. MLlett \& Peter MAslowski, For the COMMON Defense: A MILITARY HISTORY OF THE UNITED STATES OF AMERICA 346-379 (rev. ed. 1994) (describing the American experience during World War I); see also EDWARD M. COFFMAN, THE WAR To END ALL WARS: THE AMERICAN MIITARY EXPERIENCE IN WORLD WAR I (1968) (describing the experience of American soldiers in World War I); B.H. LIDDELL HART, THE REAL WAR, 19141918 (1930) (documenting the history of World War I).

70. See, e.g., RICHARD N. HAASS, INTERVENTION: THE USE OF AMERICAN MILITARY FORCE IN THE POST-COLD WAR WORLD 37-48 (1994) (describing recent cases of American military peacekeeping in the former Yugoslavia, Somalia, and Haiti). See generally THE MILITARY IN NEW TIMES: ADAPTING ARMED FORCES TO A TURBULENT WORLD (James Burk ed., 1994).

71. See generally JEANNE HOLM, WOMEN IN THE MILITARY: AN UNFINISHED REVOLUTION (1992) (tracing the roles of women in the armed forces); SHERIE MERSHON \& STEVEN SCHLOSSMAN, FOXHOLES AND COLOR LINES: DESEGREGATING THE ARMED FORCES (1998) (tracing the racial integration of the military). 
military bases throughout the world. Furthermore, although infantry and artillery are still essential parts of the armed forces, the sophistication and diversity of modern weapons have created multiple environments in which servicemembers labor. The technologically advanced, professional, standing armed forces are not so "separate" a society as perhaps they once were, and all soldiers are not subjected to exceptionally close scrutiny. ${ }^{72}$ Wigmore's argument that the military environment exposes all weaknesses may be true for certain servicemembers in certain situations, but it cannot be elevated to a maxim valid for the armed forces in general. ${ }^{73}$

\section{Separating Sentencing from Guilt: Colonel Winthrop}

Unlike Dean Wigmore, Colonel Winthrop declined to elaborate on any special conditions of military life that might justify extensive use of character evidence. ${ }^{74}$ In a brief discussion of the admissibility of good character evidence in defense, Winthrop made no mention of whether soldiers are subject to heightened surveillance or whether war and military service expose the truth of character with more accuracy than civil life. In fact, Winthrop noted that evidence of good character is "usually intended partly or principally, as in mitigation of the punishment which may follow upon conviction" 75 rather than as evidence on the merits. Admitting good character evidence during sentencing-not during the deliberative phase of a court-martial-was the practice described and advocated by Colonel Winthrop. ${ }^{76}$

72. For one example of the limited surveillance that occurs in modern military life, consider the current anti-gay policy of the armed forces, “Don't ask, don't tell, don't pursue." See Policy Concerning Homosexuality in the Armed Forces, 10 U.S.C.A. \$ 654 (West 1997). If servicemembers can, and in fact are advised to, hide their sexual orientation from commanders and military peers, then they cannot be subject to the all-encompassing scrutiny that Wigmore evoked.

73. Wigmore's second distinctive feature of soldierly life, the constant observation of servicemembers by superiors, is also valid for only a limited portion of the total military population. In fact, the most scrutinized servicemembers are troops with low rank and few privileges, since privacy and autonomy increase with military rank. Paradoxically, then, the leastscrutinized servicemembers - those of high rank-are most likely to benefit from the good soldier defense. High-ranking servicemembers may have been scrutinized early in their careers, but they are far removed from the scrutiny of "life in the trenches" if charged with an offense late in their service careers.

74. See WINTHROP, supra note 32 , at 350-52.

75. Id. at 351 .

76. A single line of Winthrop's volume has been cited in support of the greater relevance of good character at courts-martial as opposed to civilian trials: "In a military case, not only is such testimony relevant as goes to the gist of the particular defence, but also such as may establish good character ...." Id. at 320; see, e.g., Capofari, supra note 11, at 173 . Winthrop made this statement in a discussion of relevance, referring specifically to testimony of the accused, not of the accused's character witnesses. The end of the sentence, omitted in Capofari's citation, reads "or avail to extenuate the punishment in case of conviction." WNIHROP, supra note 32, at 320 . Taken together with Winthrop's lengthier subsequent treatment of character evidence, this 
Aside from his central focus on the importance of character in determining an appropriate sentence, Winthrop's comments that character evidence is "always admissible" 77 contradict the restrictions on evidence of character required by the Military Rules of Evidence. ${ }^{78}$ Despite his concerns with the special contexts of military law, Winthrop never defined "military character" as a unique trait, nor elaborated a special role for such a trait at court-martial. In short, Winthrop's treatise does not support the contention that the exigencies of military life somehow attach greater probative value to evidence of military character than generic "good citizen" evidence in a civilian trial.

Taken together, the "separate society" argument, Wigmore's World War I writings, and Winthrop's treatise do not provide a sufficient legal rationale for using general good military character to assess criminal liability. The range of good military character evidence that may be admitted at courts-martial goes far beyond narrowly tailored testimony about honesty or credibility and into the vaguely defined realm of character assessment. That misty realm is the subject of the next Part. ${ }^{79}$

\section{WHAT MAKES A SOLDIER GOOD?}

Few judges, practitioners, or scholars of military law have attempted to define "good military character," despite its prominence in justifications for the good soldier defense. ${ }^{\$ 0}$ Most would agree, however, on a basic set of attributes along the lines of Colonel Winthrop's partial list of the good soldier's "traits or habits": "efficiency, fidelity, subordination, temperance, [and] courage." ${ }^{81}$ Such general agreement about the ideal characteristics of

quotation supports my argument that Winthrop intended that character evidence be used in mitigation of sentencing rather than as exculpatory evidence during findings.

77. WINTHROP, supra note 32 , at 351.

78. See MiL. R. EVID. 404(a).

79. Both of the major published treatments of good military character evidence quote Judge Learned Hand on the subject of character evidence: "The subject seems to gather mist which discussion serves only to thicken, and which we can scarcely hope to dissipate by anything further we can add." Lieutenant Colonel Richard R. Boller, Proof of the Defendant's Character, 64 MIL. L. REV. 37, 37 (1974) (quoting Nash v. United States, 54 F.2d 1006, 1007 (2d Cir. 1932); Capofari, supra note 11, at 171 (same). Boller and Capofari accepted Judge Hand's conception of character evidence as an impenetrable mist; I do not. While the definition of character is indeed elusive, clarifying its meaning seems particularly important if it is to play so significant a role at trial. An "I know it when I see it" definition is hardly appropriate. Cf. Jacobellis v. Ohio, 378 U.S. 184, 197 (1964) (Stewart, J., concurring).

80. But see United States v. Gagan, 43 M.J. 200, 202 (C.A.A.F. 1995) (explaining that character involves both "a pattern of repetitive behavior" and behavior that is "morally praiseworthy" in holding that heterosexuality is a relevant character trait in a court-martial for homosexual sodomy).

81. WINTHROP, supra note 32, at 351; see also United States v. Vandelinder, 20 M.J. 41, 45 (C.M.A. 1985) ("Admittedly, a diversity of views may exist as to the precise limits of 'good military character.'... Nonetheless, we are convinced that the term has a generally understood 
a good soldier does not solve the difficulty of defining the single trait termed "good military character." If good military character is so distinct from generic good character that it deserves special due at courts-martial, then the qualities of the "good soldier" should be clear.

This Part explores the parameters of "good military character," searching for a plausible definition of good soldiers and a better understanding of the traits they are most likely to possess. Opinions of military courts, treatises, and military evaluations describe military character in disparate ways. These descriptions draw attention to the contradictions contained within the concept as well as the absence of definable, military-specific aspects of military character.

\section{A. "I'd go to war with him": The Character of the Warrior}

Perhaps the most essential yet elusive quality of the good soldier is reliability during war. Victory in war is the raison d'être of the military itself; whatever qualities make soldiers effective during violent conflict must be part of the definition of the good soldier. Not surprisingly, courtsmartial routinely admit good soldier testimony asserting that an accused performed well on the battlefield, or that he would perform well, given the opportunity. Highlighting an accused servicemember's good record during past conflicts is a common defense tactic ${ }^{82}$ as is introducing evidence that military peers "would want to be deployed with" 83 the accused or "would want [the accused] by [their] side" 84 during combat.

Most servicemembers would agree that describing a fellow soldier as someone with whom they would want to go to war is a powerful statement of good military character, but that consensus does little to dispel the uncertainty that plagues the term. A "good soldier" during war may also be a person likely to commit crimes or a person prone to violent behavior. ${ }^{85}$ While Winthrop's loyal, brave, just, and true good soldier may be one face of the ideal warrior, combat effectiveness involves a myriad of character

core of meaning and that, when a witness testifies about an accused's military character, the factfinder understands generally what is meant.").

82. See, e.g., United States v. Crum, 38 M.J. 663, 665 (A.C.M.R. 1993); United States v. Condron, 37 C.M.R. 688, 690 (A.B.R. 1967).

83. See, e.g., United States v. True, 41 M.J. 424, 427 (C.A.A.F. 1995).

84. United States v. Hallum, 31 M.J. 254, 255 (C.M.A. 1990); see, e.g., United States v. Craddolph, 36 C.M.R. 688, 689 (A.B.R. 1966).

85. Apart from the difficulty of separating the violent good soldier in war from the pacific good soldier during peacetime, there is evidence that the rates of some crimes among servicemembers rise during war, supporting the intuitive conclusion that women and men in combat are less, rather than more, likely to adhere strictly to laws. See Simon Chesterman, Never Again . . . and Again: Law, Order, and the Gender of War Crimes in Bosnia and Beyond, 22 YALE J. INT'L L. 299 (1997); Madeline Morris, By Force of Arms: Rape, War, and Military Culture, 45 DUKE L.J. 651 (1996). 
traits that do not fit seamlessly into an image of law-abiding, truth-telling servicemembers. War requires violence, aggression, and sometimes irrational behavior. Such evidence seems at best marginally probative, and more likely irrelevant, in determining whether an accused servicemember committed a specific criminal act.

Even if combat heroics and reliability during war do lessen the likelihood of a soldier's committing a crime, the character traits that make up the "good combat soldier" are neither transparent nor complementary. No single description can encompass the variety of personalities and "characters" that make up a successful modern fighting force. The intrepid captain of a nuclear submarine, the cerebral code-breaker, the ace fighter pilot, the meticulous supply sergeant, the reckless paratrooper, the selfless medic-although each is a key part of the armed forces, they share few essential character traits as a group.

The limited trial transcripts quoted in appellate records suggest direct contradictions about what it means to be an effective combat soldier. In one case the accused is termed "aggressive" $;{ }^{86}$ in another, "pretty mellow" and "easygoing." 87 At times, the inconsistencies are a natural result of the different opinions of witnesses. For example, in United States v. Looney, a recent court-martial of an Army private for murder, the defendant was described as "a peaceful, nonviolent person and a good soldier" in some testimony and as a knife-wielding aggressor by others. ${ }^{88}$ The Looney testimony points out the difficulty of separating the behavior of a "good soldier" from the behavior of a violent felon. The private had "displayed a knife to his companions and indicated that he was 'ready' if any trouble broke out and that he had the group "covered." 89 This might indicate that he is a dangerous individual, or it might just as well reveal a loyal soldier prepared to protect himself and his comrades. The definition of a good soldier thus depends on the assumptions of the witnesses, the requirements of the servicemember's military duty, and the particular situation. Because the good soldier defense admits evidence of so many different traits, assertions of "good military character" are inevitably incoherent.

\section{B. "He's always on time": The Bureaucratic Soldier}

Identifying and retaining soldiers who can win wars is a primary goal of military institutions, but most of a servicemember's career is spent preparing to fight, not fighting. In the contemporary armed forces, being a good soldier entails many skills and character traits that cannot be described

86. United States v. Begley, 38 C.M.R. 488, 496 (A.B.R. 1967).

87. True, 41 M.J. at 427.

88. United States v. Looney, 48 M.J. 681, 683 (A. Ct. Crim. App. 1998).

89. Id. (internal citation omitted). 
as especially military, and few that qualify as martial. One author writing about "good military character" asked whether being a good soldier meant a soldier who is "always on time for work, keeps his shoes shined, and does his job adequately." "The answer according to the case law is yes: A good soldier does all of those things, revealing the strong similarity between the good soldier and the good civilian employee. ${ }^{91}$

Not surprisingly, descriptions of an accused's good military character often read much like descriptions of generic good character, absent any special military flavor. Good soldiers have been deemed prompt $^{92}$ dependable, ${ }^{93}$ apt to take the initiative, ${ }^{94}$ capable, and proficient. ${ }^{95}$ "Good military character" testimony often reveals more about the accused's attractive personality ("well-liked" 96 ) and people skills ("excellent rapport with supervisors, patients, and staff" ${ }^{97}$ ) than warrior spirit or performance under fire. Such assessments do little to support the notion that "good military character" defines anything more than general good character and adaptability, evidence of which would likely be deemed irrelevant, distracting, and inadmissible at a civilian criminal trial.

\section{Performance Reports: Categorical Character}

Although good soldier evidence most frequently consists of live testimony or individual affidavits, it may also include the accused's military performance reports. These periodic appraisals help commanders evaluate servicemembers for promotion, award, and assignment decisions. The categories of performance set out on evaluation forms further illuminate the imprecise nature of the "good soldier."

90. Captain Robert Smith, Military Rule of Evidence 404(A)(1): An Unsuccessful Attempt To Limit the Introduction of Character Evidence on the Merits, 33 FED. B. NEWS \& J. 429, 432 (1986).

91. In fact, the armed forces themselves use the continuity between civilian and military life for recruiting purposes. Recall the Army television commercial in which a camouflaged soldier strides forward during a training exercise in the field only to be transformed before the eyes of the viewer into a businessman, clad in suit and tie and carrying a briefcase instead of a weapon. Such efforts are not new; recruiters for the armed forces during World War II stressed the continuity between civilian and military life. See Benjamin L. Alpers, This Is the Army: Imagining a Democratic Military in World War II, 85 J. AM. HIST. 129, 139 (1998) (noting that the good soldier was explicitly equated with the good citizen in Army recruiting campaigns during World War II).

92. See, e.g., United States v. Brown, 41 M.J. 1, 7 (C.M.A. 1994); United States v. Vandelinder, 20 M.J, 41, 42 (C.M.A. 1985).

93. See, e.g., Brown, 41 M.J. at 7; United States v. White, 36 M.J. 306, 307 (C.M.A. 1993). 1966).

94. See, e.g., Brown, 41 M.J. at 7; United States v. Craddolph, 36 C.M.R. 688, 689 (A.B.R.

95. See, e.g., White, 36 M.J. at 307.

96. See, e.g., United States v. Hallum, 31 M.J. 254, 255 (C.M.A. 1990).

97. See, e.g., White, 36 M.J. at 307. 
In one of the most important cases broadening the admissibility of good character evidence under Rule 404(a)(1), the Court of Military Appeals assessed the admissibility of performance reports offered as evidence of the accused's good character. ${ }^{98}$ The reports denoted five categories of evaluation: professional performance, military behavior, leadership and supervisory ability, military appearance, and adaptability. ${ }^{99}$ These categories are typical of the standardized evaluation forms used to rate servicemembers in every branch, and at every rank, of the armed forces. ${ }^{100}$ Only two categories, military appearance and military behavior, involve traits uniquely important to servicemembers. "Professional performance" is defined on the form as "skill and efficiency in performing assigned duties," 101 reflecting an assessment of capability, not of character. "Leadership and supervisory ability" is described as the "ability to plan and assign work to others," ${ }^{102}$ again, a managerial, and not militaryspecific, skill that has little to do with the assessment of character. "Adaptability" refers to " $[\mathrm{h}]$ ow well [the] member gets along and works with others," an index of personality type rather than a unique "military character." 103

The two remaining "military" traits on the evaluation form are defined as "[h]ow well [the] member accepts authority and conforms to standards of military behavior" and the "[m]ember's military appearance and neatness in person and dress." 104 Taken together, these categories of "character" measure conformity to rules, which may indeed be predictive of lawful, rather than law-breaking, behavior. They also stress, however, the personal appearance of the individual over capability and actual performance, raising fundamental issues of fairness. By focusing on physical attributes and patterns of behavior instead of abstract "character," admission of this type of evidence privileges a defendant who conforms to stereotypes of appearance and conduct over others who might be dependable, even heroic, soldiers, but fail to look the part. Female soldiers are capable of performing equally as well as servicemen, but most do not

98. See United States v. Vandelinder, 20 M.J. 41, 42 (C.M.A. 1985).

99. See id. at $42-43$.

100. These forms vary from service to service, and the categories change slightly depending on the rank of the servicemember. For instance, officer evaluation forms emphasize leadership skills and potential, while the evaluations of junior enlisted soldiers stress adaption to military life and ability to follow. For the Air Force versions of these forms, see Field Grade Officer Performance Report, A.F. FORM 707A (Oct. 1995); Company Grade Officer Performance Report, A.F. FORM 707B (Oct. 1995); Senior Enlisted Performance Report, A.F. FORM 911 (June 1995); and Enlisted Performance Report, A.F. FORM 910 (June 1995).

101. Vandelinder, 20 M.J. at 48.

102. Id.

103. Id.

104. Id. 
look as sharp and "soldierly" as men in military uniforms. ${ }^{105}$ Likewise, African-American servicemembers often do not fit as easily into military traditions of appearance and behavior, and they have a long history of being disproportionately censured for disobedience and nonconformity. ${ }^{106}$ Evidence of conformity is apt to reflect prejudicial assumptions of courtmartial members who must assess whether a servicemember committed a particular criminal act.

Aside from its potential to bring irrelevant and discriminatory evidence into courts-martial, the liberal admission of military evaluations as good soldier evidence poses other difficulties. Military personnel recognize that evaluations often reflect, at best, a rosy image of the servicemember being evaluated, and at worst, a ridiculous overstatement of individual capabilities and performance. ${ }^{107}$ Perhaps court-martial members can decipher the hyperbolic language of performance reports, but that is little reason to admit such overblown testimony into courts of law.

The inability of so many judges and commentators to define "good military character" is not surprising, given its multiple and contradictory meanings. The vagueness that surrounds "good soldier" evidence, combined with its lack of special military content, raises basic questions about its privileged place at courts-martial. The good soldier possesses many laudable traits, but no single set of praiseworthy behaviors and tendencies makes soldiers good, nor distinguishes them from civilian

105. See, e.g., JUDITH HICKS STIEHM, BRING ME MEN AND WOMEN 251-52 (1981); Elizabeth Lutes Hillman, Uniform Identities: Women, Gender, and Images at the United States Service Academies 14-68 (1994) (unpublished M.A. thesis, University of Pennsylvania) (on file with author) (describing how the design and wear of women's uniforms at the United States Air Force Academy marginalizes female cadets).

106. See, e.g., LeO Bogart ET AL., Social Research AND THE DESEgregation OF THE U.S. ARMY: TWO ORIGINAL 1951 FIELD REPORTS 58-60 (Leo Bogart ed., 1969) (documenting the racist attitudes of white soldiers and the disparate treatment of African-American troops during the early phases of the Army's effort to desegregate); LEONARD F. GUTTRIDGE, MUTINY: A HISTORY OF NAVAL INSURRECTION 255-84 (1992) (describing the racial tension on-board naval ships in the early 1970s); RICHARD O. HOPE, RACIAL STRIFE IN THE U.S. MILITARY: TOWARD THE ELIMINATION OF DISCRIMINATION (1979); SHIRLEY JOLLS, KANGAROO COURTMartial: GeORge Daniels and WILliam HaRVEY, TWo BlaCK MaRINES Who Got SIX AND TEN YEARS FOR OPPOSING THE VIETNAM WAR 3-5 (1969) (characterizing the military justice system as a dictatorship that unduly punished Daniels and Harvey for their alleged "disloyalty"); JOHN F. MARSZALEK, ASSAULT AT WEST POINT: THE COURT-MARTIAL OF JOHNSON WHITTAKER (1972) (describing the court-martial of an African-American West Point cadet); Charles M. Robinson III, THE Court-Martial of Lieutenant HenRY Flipper (1994) (same).

107. See, e.g., United States v. Harris, 34 M.J. 297, 301 (C.M.A. 1992) (noting the uniformly "outstanding" evaluations of the accused); United States v. Graham, 46 M.J. 583, 584 (A.F. Ct. Crim. App. 1997) (describing a master sergeant's "firewall" performance reports); United States v. Magraw, 1996 WL 927686, at *5 (N-M. Ct. Crim. App. May 8, 1996) (demonstrating grade inflation by describing one evalution of 3.8 and two of $3.6-$ on a 4.0 scale- as "not the kind of glowing evaluations" that would demonstrate good military character). 
counterparts. Vagueness is a troubling feature of military law in general, ${ }^{108}$ and the evidentiary doctrine that allows admission of general good character evidence is no exception. For all these reasons, the military judiciary's resistance to the limitations on character evidence adopted by the Military Rules of Evidence adheres to a practice of doubtful utility.

\section{THE “GoOd SOldIER” DefEnse IN PRACTICE}

The questionable justifications and lack of clarity that surround the good soldier defense would be less significant if evidence of good military character were admitted infrequently or in only certain types of cases. Instead, evidence of good military character is admitted in courts-martial for any offense under the Uniform Code of Military Justice. ${ }^{109}$ This Part discusses the "good soldier" defense in practice, outlining how the defense is used at different types of courts-martial. While evidence of good military character may qualify as a "pertinent trait" in courts-martial for military offenses, the good soldier defense also permits evidence of good military character to enter into the guilt phase of trials for nonmilitary offenses. By failing to limit good soldier testimony to those trials in which military behavior is at issue, military judges have broadened the good soldier evidentiary doctrine beyond its logical applications.

\section{A. Military Offenses}

Courts-martial for offenses defined as "military" present the strongest case for admitting evidence of good military character. Because military law penalizes many acts that are not criminal under civilian law, some of the offenses charged at court-martial cannot be committed by civilians. The good soldier defense is most effective at courts-martial for these military

108. See, e.g., 10 U.S.C. $\$ \S 933-934$ (1994) (criminalizing "conduct unbecoming an officer and a gentleman," "all disorders and neglects to the prejudice of good order and discipline," and "all conduct of a nature to bring discredit upon the armed forces").

109. See, e.g., United States v. Gleason, 43 M.J. 69 (C.A.A.F. 1995) (involving a sergeant major convicted of solicitation to commit murder); United States v. Condron, 38 C.M.R. 165 (C.M.A. 1968) (involving a sergeant E-5 convicted of murdering two Vietnamese civilians in his tent); United States v. Schoffler, 1996 WL 208810 (A.F. Ct. Crim. App. Mar. 22, 1996) (involving an airman first class convicted of aggravated assault against his ex-wife and her boyfriend); United States v. Crum, 38 M.J. 663, 663 (A.C.M.R. 1993) (involving a private first class convicted of "secreting mail bags and of opening specified mail"); United States v. Begley, 38 C.M.R. 488 (A.B.R. 1967) (involving a sergeant E-5 convicted of involuntary manslaughter for his role in feigning hostile fire in order to appear effective to superiors and then killing a Vietnamese civilian by firing in response); United States v. Ruiz-Rosa, 37 C.M.R. 591 (A.B.R. 1966) (involving a private convicted of assault with intent to commit murder); United States v. Baguex, 2 C.M.R. 424 (A.B.R. 1952) (involving a private first class convicted of the murder of another private). 
offenses, ${ }^{110}$ particularly for relatively minor charges, ${ }^{111}$ such as "conduct unbecoming an officer and a gentleman," ${ }^{112}$ abuse of authority, ${ }^{113}$ disobedience, ${ }^{114}$ and being absent without leave. ${ }^{115}$ In short, good military character, presuming that it indicates at least something about an accused's dedication to the military and duty performance, is most probative in courts-martial for military offenses. ${ }^{116}$

Admitting generic good military character evidence in courts-martial for military-specific offenses seems consistent with the intent and meaning of Military Rule of Evidence 404(a)(1); surely "military character" is a pertinent trait when a servicemember is accused of being disrespectful, disloyal, sloppy, or otherwise unsoldierly. Determining what constitutes a "military" as opposed to a "non-military" offense, however, may call for a nuanced analysis and careful weighing of multiple factors. ${ }^{117}$ Faced with the difficulty of making a rule to distinguish "service-connected" from "nonservice-connected" offenses, the Supreme Court opted to expand courtmartial jurisdiction instead. ${ }^{118}$ In the context of sex crimes and sexual harassment, a line between a military and a nonmilitary offense is especially difficult to draw, since an accused often has abused his position of authority in order to commit an offense not specific to the military. In any case, the practice of restricting good soldier testimony to courts-martial involving military offenses was abandoned soon after the adoption of the Military Rules of Evidence, when military courts eliminated the requirement for a "nexus" between military duty and the charged offense. ${ }^{119}$

110. Interview with Stephen D. Smith, supra note 39 (noting that the good soldier evidence is most powerful if the charges involve a violation of a military duty).

111. Interview with Monty Forrester, supra note 39 (noting that, in general, the good soldier defense is more effective when the criminal charges are relatively minor).

112. See, e.g., United States v. Belz, 20 M.J. 33 (C.M.A. 1985) (involving a "conduct unbecoming an officer and a gentleman" offense based on various drug-related charges).

113. See, e.g., United States v. Piatt, 17 M.J. 442 (C.M.A. 1984) (involving a drill sergeant convicted of ordering two trainees to beat up a third).

114. See, e.g., United States v. Brewer, 39 C.M.R. 388 (A.B.R. 1968) (upholding the conviction of a private first class for willful disobedience).

115. See, e.g., United States v. Sims, 22 C.M.R. 591 (A.B.R. 1956) (upholding the conviction of a private for being absent without leave).

116. See, e.g., United States v. Kahakauwila, 19 M.J. 60, 61-62 (C.M.A. 1984) ("It would seem apparent that for those offenses which are militarily oriented, evidence of conformance to military standards would be relevant.").

117. Myriad factors may be taken into account here, including the article under which the accused is charged and whether the conduct took place during peacetime or war, on or off a military base, in or out of uniform, and among servicemembers or civilians. See Relford v. Commandant, 401 U.S. 355, 365 (1971) (setting out the factors to be considered in determining a service connection).

118. See Solorio v. United States, 483 U.S. 435, 439 (1987) (expanding court-martial jurisdiction by eliminating the requirement that offenses subject to trial at court-martial be "service-connected").

119. See, e.g., Capofari, supra note 11, at 184-85. Despite the breadth of the character exception, some practitioners believe that good military character evidence is effective only when 


\section{B. "Nonmilitary" Offenses}

Unlike military-specific offenses involving disobedience or insubordination, charges involving the use of illegal drugs and sex crimes are common in both civilian and military courtrooms. Only servicemembers at courts-martial, however, can use the good soldier defense when accused of these crimes. The good soldier defense is a common tactic at courtsmartial for both drug offenses ${ }^{120}$ and sex crimes. ${ }^{121}$ Drug and sex crimes, which are more broadly defined under military law than under most civil criminal codes, may have profound consequences for good order and discipline among servicemembers. But these offenses do not generally

the charges involve military offenses. See Morris, supra note 29, at 22 ("Most good soldier defenses that do not relate to military offenses are useless and not worth the expenditure of counsel energy to research and rebut."); Interview with Frederick Kennedy, supra note 39 (noting that, in general, evidence of good military character "makes the most difference" in courtsmartial for military-type offenses); Interview with Stephen D. Smith, supra note 39 (explaining the greater utility of the good soldier defense at courts-martial for military-specific crimes).

120. See, e.g., United States v. White, 36 M.J. 306 (C.M.A. 1993) (involving a sergeant convicted of cocaine use); United States v. Harris, 34 M.J. 297 (C.M.A. 1992) (convicting a staff sergeant of distributing cocaine); United States v. Hallum, 31 M.J. 254 (C.M.A. 1990) (convicting a private first-class for distributing marijuana); United States v. Hurtt, 22 M.J. 134 (C.M.A. 1986) (convicting a sergeant for selling marijuana); United States v. Vandelinder, 20 M.J. 41 (C.M.A. 1985) (convicting an airman apprentice, an enlisted man in the Navy, of selling a controlled substance); United States v. Weeks, 20 M.J. 22 (C.M.A. 1985) (reversing the conviction of a gunnery sergeant for possessing, transferring, and selling marijuana because the military judge did not admit evidence of good military character); United States v. Kahakauwila, 19 M.J. 60 (C.M.A. 1984) (upholding a corporal's conviction for selling marijuana); United States v. Graham, 46 M.J. 583 (A.F. Ct. Crim. App. 1997) (involving a master sergeant convicted of marijuana use); United States v. Harris, 1995 WL 261962 (A.F. Ct. Crim. App. Apr. 27, 1995) (convicting a staff sergeant of cocaine use); United States v. Tipton, 34 M.J. 1153 (A.C.M.R. 1992) (convicting a sergeant for marijuana and cocaine use); United States v. Cooper, 11 M.J. 815 (A.F.C.M.R. 1981) (convicting a senior airman for possession of marijuana); United States v. Mills, 7 M.J. 664 (A.C.M.R. 1979) (convicting a specialist-five for attempting to sell heroin and possessing marijuana).

121. See, e.g., United States v. Gagan, 43 M.J. 200 (C.A.A.F. 1995) (convicting a lieutenant commander of forcible sodomy with enlisted sailors, indecent assault, and assault and battery); United States v. Boone, 42 M.J. 308 (C.A.A.F. 1995) (involving a rape charge against an Army specialist); United States v. True, 41 M.J. 424 (C.A.A.F. 1995) (convicting an airman first class of rape and indecent assault); United States v. McNeill, 17 M.J. 451 (C.M.A. 1984) (involving a drill sergeant convicted of sodomy with an officer-candidate trainee under his command); United States v. Hannah, 1998 WL 88122, at *3 (N-M. Ct. Crim. App. Feb. 18, 1998) (convicting a sergeant E-5 for, inter alia, forcible sodomy and indecent exposure, in which the defense team presented "extensive evidence of the appellant's good military character to show that he did not commit the offenses in question"); United States v. Reed, 44 M.J. 825 (A.F. Ct. Crim. App. 1996) (convicting a staff sergeant for indecent acts and attempted sodomy with his then fourteen-yearold niece); United States v. Black, 42 M.J. 505 (A. Ct. Crim. App. 1995) (convicting a sergeant first class of rape and forcible sodomy); United States v. Wilson, 23 M.J. 899 (A.C.M.R. 1987) (convicting a sergeant first class of sodomy, adultery, indecent language, and assault consummated by battery); United States v. Craddolph, 36 C.M.R. 688, 688 (A.B.R. 1966) (convicting a sergeant E-5 for "burglariously breaking and entering a dwelling house with intent to commit an indecent assault therein and the offense of committing an indecent assault on the wife of a serviceman, with intent to gratify his [the accused's] lust and sexual desires"); United States v. Baguex, 2 C.M.R. 424 (A.B.R. 1952) (convicting a private of murder). 
involve the sort of military-specific crimes in which good soldier evidence is most easily justified. ${ }^{122}$ Since drug and sex crime trials are often contested, involving extensive battles of credibility, good soldier testimony can be decisive. ${ }^{123}$ Admitting evidence of good military character at courtsmartial for drug and sex offenses further reveals the troubling presumptions about character and criminality that are validated by the good soldier defense.

After a short-lived debate in the military judiciary over whether good military character was relevant in drug cases, the Court of Military Appeals held that good soldier evidence was admissible in all cases of alleged drug use. ${ }^{124}$ Based on the presumption that drug abuse has uniquely pernicious consequences for military personnel, accused servicemembers could henceforth argue that they did not abuse drugs because they were "good soldiers." Intuitively, a "good" soldier is less likely to possess or sell illegal drugs than a "bad" soldier, but such an assumption is no better substantiated in a military environment than a comparable civil situation, in which general good character evidence would not be relevant. ${ }^{125}$ Character evidence focuses the trier of fact's attention on the person, rather than the alleged criminal act in question, suggesting that accused servicemembers should be punished-or exonerated - for their status or personality. If the objective is to bolster the credibility of the accused, who commonly claims innocent ingestion or mistaken lab results in these cases, then courts-martial

122. See supra text accompanying notes $110-19$.

123. Interview with William D.S. Dixon, supra note 39 (explaining that good military character evidence "matters tremendously any time the trial is close"). Most observers agree that in courts-martial for very serious charges (such as murder), or when the evidence of guilt is overwhelming, the good soldier defense has little effect on the outcome. My focus here is on the cases in which admitting evidence of good military character can make the most difference.

124. Four decisions, all handed down on the same day in 1985 , held general military character relevant to drug charges. See United States v. Traveler, 20 M.J. 35 (C.M.A. 1985); United States v. Belz, 20 M.J. 33 (C.M.A. 1985); United States v. Wilson, 20 M.J. 31 (C.M.A. 1985); United States v. Weeks, 20 M.J. 22 (C.M.A. 1985). The Court of Appeals for the Armed Forces has recognized limits on the form and scope of evidence admissible under the good soldier defense in drug cases, but has not relented on its relevance. See United States v. Schelkle, 47 M.J. 110,112 (C.A.A.F. 1997) (upholding a military judge's decision not to admit observation of general good conduct as part of a good soldier defense in the case of an Air Force major convicted of marijuana use).

125. See, e.g., Lieutenant Colonel Stephen R. Henley, Developments in Evidence III-The Final Chapter, ARMY LAW., May 1998, at 1, 6 ("I]t is beyond doubt that a person can be a good military performer and still abuse drugs."). The doubtful relevance of character testimony-and its potential value in convincing a court-martial to acquit-has been implicitly acknowledged by commanders who have advised accused servicemembers' peers and supervisors not to testify on the accused's behalf. Such advice has been properly held to constitute unlawful command influence under Article 37. See, e.g., United States v. Thomas, 22 M.J. 388, 400 (C.M.A. 1986); United States v. Treakle, 18 M.J. 646, 651 (A.C.M.R. 1984) (quoting a letter from a Brigade Command Sergeant Major advising that "Noncommissioned Officers DON'T ... [s]tand before a court-martial jury .... and state that even though the accused raped a woman or sold drugs, he is still a good soldier on duty."). 
could simply admit evidence of veracity, a truly pertinent character trait, in assessing whether an accused is lying about alleged drug use. ${ }^{126}$

Like drug trials, courts-martial for sex crimes often involve battles of credibility between the accused and the prosecution's witnesses. The legal terrain of the good soldier defense is complicated in trials for sex crimes by rape shield laws that limit the admissibility of character evidence about victims of sexual assault, ${ }^{127}$ the wide range of sexual acts criminalized under military law, ${ }^{128}$ and the ongoing evidentiary debate over the admissibility of evidence of prior acts of sexual assault by alleged rapists. ${ }^{129}$ Given the number of sex crimes prosecuted under the Uniform Code of Military Justice and the pervasive nature of sexual harassment in the armed forces, ${ }^{130}$ the use of the good soldier defense in sex crime courts-martial is particularly significant. ${ }^{131}$

126. The prosecution sometimes benefits more from this practice than the defense. "Opening the good soldier door" allows the prosecution to rebut with evidence of past bad acts and propensity, which can be the tuming point in a drug trial that boils down to a conflict between sworn testimonies. As a result, the decision to use the good soldier defense is an important tactical choice. See, e.g., United States v. Graham, 46 M.J. 583, 586 (A.F. Ct. Crim. App. 1997) (involving the admission of prior uncharged misconduct to rebut evidence of the accused's "sterling military career and character"); United States v. Pruitt, 43 M.J. 864, 867 (A.F. Ct. Crim. App. 1996) ("[T] he accused holds the key to the character closet.").

127. See FED. R. EVID. 412; MIL. R. EVID. 412; JoEL EPSTEIN \& STACIA LANGENBAHN, THE CRIMNAL JUSTICE AND COMMUNITY RESPONSE TO RAPE (1994); SUSAN ESTRICH, REAL RAPE (1987); CASSIA SPOHN \& JULIE HORNEY, RAPE LAW REFORM: A GRASSROOTS REVOLUTION AND ITS IMPACT (1992); Ronald J. Berger et al., Rape-Law Reform: Its Nature, Origins, and Impact, in RAPE \& SOCIETY: READINGS ON THE PROBLEM OF SEXUAL ASSAULT 223, 223-32 (Patricia Searles \& Ronald J. Berger eds., 1995).

128. All lesser sex crimes other than sodomy, which is prosecuted under Article 125, are prosecuted under Articie 134, the "general article" of the Uniform Code of Military Justice. See MANUAL FOR COURT-MARTIAL, UNITED STATES, Part IV, 191 62 (adultery), 63 (indecent assault), 65 (bigamy), 69 (wrongful cohabitation), 83 (fraternization), 87 (indecent acts with a child), 88 (indecent exposure), 90 (indecent acts with another), \& 97 (pandering and prostitution) (1995).

129. See FED. R. EVID. 413; MIL. R. EvID. 413; Katharine K. Baker, Once a Rapist? Motivational Evidence and Relevancy in Rape Law, 110 HARV. L. REV. 563 (1997) (analyzing the implications of FED. R. EVID. 413).

130. See, e.g., WILliam S. COHEN, SECRETARY OF DEFENSE, ANNUAL REPORT to THE PRESIDENT AND THE CONGRESS App. G, Table G-2 (1998) (reporting on the high number of sexual harassment complaints filed with the Department of Defense between 1987 and 1996); MARGARET C. HARRELL \& LAURA L. MILLER, NEW OPPORTUNITIES FOR MILITARY WOMEN: EFFECTS UPON READINESS, COHESION, AND MORALE 73-77 (1997); Sara Eckel, Editorial, The War in the Ranks of the Military, SACRAMENTO BEE, Feb. 24, 1997, at B7 ("[T]here's no doubt that [sexual harassment of women in the military] is pervasive.").

131. By discussing courts-martial for different types of sex crimes together in this Part, I do not wish to imply that minor sex crimes are indistinguishable from grave offenses such as rape, nor do I wish to suggest that such "crimes" as consensual sodomy or adultery ought to be prosecuted in criminal proceedings. For the purposes of undermining the broad, illogical sweep of the good soldier defense, classifying these offenses into a category is a useful analytical tool, since it demonstrates the breadth of admissibility of good military character. Not all sex crimes in the military would be treated as crimes in civilian jurisdictions-and not all offenses rooted in discrimination and prejudice are sexual in nature. For example, see Vicki Schlutz's discussion of non-sexualized behavior that nonetheless constitutes sexual harassment in Reconceptualizing Sexual Harassment, 107 YALE L.J. 1683, 1694 (1998), which argues that the armed forces' 
Military judges admit evidence of good military character without any empirical data that "good soldiers" rape, or commit other sex crimes, with any less frequency than "bad" soldiers or "good" civilians. ${ }^{132}$ A recent case demonstrates how clearly the good soldier defense violates the general rule against propensity evidence when applied in courts-martial for sex crimes. In United States v. Tiegs, the Navy-Marine Corps Court of Criminal Appeals reversed a conviction for child molestation, holding that ineffective assistance of counsel invalidated the result. ${ }^{133}$ The defense counsel's failure to employ a character defense was held reversible error because the witnesses not brought forward would have not only testified to "appellant's good general military character," but also "were prepared to attack the very notion that the appellant would commit the charged offense." ${ }^{134}$ Thus, the naval appellate court found error based on the failure to bootstrap otherwise inadmissible propensity evidence into the "good military character" exception for evidence of the accused's character. In this instance, the faulty logic behind the good soldier defense was used to justify the admission of character evidence beyond even a broad definition of "good military character."

This liberal admission of good character evidence at sex crime trials involves an assumption similar to that evident in cases of alleged drug use. Much like the message that only "bad soldiers" would abuse drugs, allowing the good soldier defense in sex crime trials creates the impression that only "bad soldiers" rape. ${ }^{135}$ Given the number of alleged rapes that are prosecuted under both civilian and military $\mathrm{law}^{136}$ in which the men implicated would otherwise appear to be "good" persons, this evidentiary doctrine allows irrelevant evidence-with a racially discriminatory

recognition of sexual advances as the exclusive realm of sexual harassment has resulted in "far less [media] coverage to other, equally debilitating forms of discrimination."

132. See, e.g., Morris, supra note 85. For more on the connections between soldiers and sexual violence against women, see BEVERLY ALLEN, RAPE WARFARE: THE HDDEN GENOCIDE IN BOSNIA-HERZEGOVINA AND CROATIA (1996); CHRISTIAN G. APPY, WORKING-CLASS WAR: AMERICAN COMBAT SOLDIERS AND VIETNAM 268-72 (1993); SUSAN BROWNMIILLER, AGAINST OUR WILL: MEN, WOMEN AND RAPE 70-71 (1975); and MASS RAPE: THE WAR AGAINST WOMEN IN BOSNIA-HERZEGOVINA (Alexandra Stiglmayer ed., 1994).

133. See United States v. Tiegs, 1997 WL 652030, *5-6 (N-M. Ct. Crim. App. June 17, 1997) (holding that defense counsel's failure to interview possible civilian character witnesses in a case involving a male E-6 accused of indecent acts with a child was grounds for reversal, since defense counsel "unilaterally gave up a key defense strategy").

134. Id. at 5.

135. See Baker, supra note 129, at 591 (explaining that the admission of prior acts evidence in rape trials "will encourage juries to focus on precisely what they are not supposed to focus on-character"). 1996).

136. See, e.g., United States v. Magraw, 1996 WL 927686 (N-M. Ct. Crim. App. May 8, 
component that cannot be ignored ${ }^{137}$ - to taint the judgment of a courtmartial.

\section{CONCLUSION: GUILT VS. PRIVILEGE}

Neither legal theory nor common sense can rationalize the current application of the evidentiary doctrine behind the good soldier defense. Basing a defense on good military character permits subjectivity, and sometimes prejudice, to enter openly into the guilt phase of courtsmartial. ${ }^{138}$ If courts-martial are impartial instruments of justice akin to civilian criminal courts, they cannot adjudge guilt or innocence based on a personal evaluation of the accused. ${ }^{139}$ The current application of the good soldier defense allows character to infiltrate the military justice system at perhaps its only objective site: the findings phase of a court-martial.

Admittedly, courts-martial are often charged with determining whether a servicemember should be retained in the military, in addition to imposing traditional criminal sanctions. This aspect of a sentencing decision is not required in civilian trials and is properly influenced by evidence of "good military character." Admission of good military character in sentencing, where it belongs, would be unaffected by stricter limits on admission of character evidence during findings.

Supported by dated arguments and preserved through resistance to statutory reform, ${ }^{140}$ the good soldier defense permits those of high rank and those who have combat experience to rely on their past service to escape censure. Predictably, the primary beneficiaries of the good soldier defense are soldiers whose long and impressive military records can overwhelm the

137. See Baker, supra note 129 , at 594-97 (explaining the racist history and culture of rape and rape laws).

138. An important treatise on military evidence published prior to the adoption of the Military Rules of Evidence notes that "the only factor militating against admissibility of evidence of good character is the possibility of confusion of issues, since no prejudice could result to the accused" from the liberal admission of good character evidence. CAPTAIN JOE H. MUNSTER \& Captain Murl A. Larkin, Military Evidence $88-89$ (2d ed. 1978). The "possibility of confusion of issues," of a court-martial panel dispensing with factfinding in favor of character analysis alone, is precisely the danger heightened by the widespread admission of character evidence. Cf. Michelson v. United States, 335 U.S. 469, 476 (1948) ("The overriding policy of excluding such [character] evidence, despite its admitted probative value, is the practical experience that its disallowance tends to prevent confusion of issues, unfair surprise and undue prejudice.").

139. In fact, this very argument has been made in support of the broad reading of Military Rule of Evidence 404(a)(1). See Smith, supra note 90, at 431 ("[G]ood soldiers, sailors, marines, airmen, and coast guardsmen do not commit crimes.").

140. See Fredric I. Lederer, The Military Rules of Evidence: Origins and Judicial Implementation, 130 ML. L. REv. 5, 33 n.118 (1990) (describing the Court of Military Appeals's decision to disregard the drafters' analysis of Military Rule of Evidence 404(a)(1) as a prime example of military judges' departure from legislative intent). 
testimony of lesser ranking or civilian accusers ${ }^{141}$-in short, those whose service records mirror the stellar career of former Sergeant Major of the Army Gene McKinney. ${ }^{142}$ The longer a soldier's length of service, the more assignments, commanders' affidavits, evaluations, and awards that can be admitted as evidence of good military character. ${ }^{143}$ This accumulation of evidence of good military character is more likely to sway a court-martial than the evidence available to a servicemember with low rank and little military experience. Aside from sheer quantity, evidence of good military character is qualitatively better for more senior accused servicemembers, since they have the benefit of contact with higher-ranking superiors, whose evaluations carry greater weight with a military factfinder. ${ }^{144}$

Defenders of the good soldier defense cannot dispute the powerful impact of high-ranking character witnesses' testimony. ${ }^{145}$ Rank is the fundamental fact of life in the military; it defines speech, dress, pay, duty, even housing. Military judges explicitly consider the rank of potential character witnesses in making judicial decisions, occasionally citing with approval the dramatic impact that the testimony of a respected superior or peer can have on a panel of court-martial members. ${ }^{146}$ When admitted on

141. See Andrea, supra note 43, at 31 ("With the right accused-a noncommissioned officer with fifteen to twenty years of service and numerous awards and commendations-using the accused's good character as a defense can be quite effective."); Morris, supra note 29, at 22 ("The more senior the accused, the more likely that the defense can craft some version of a good soldier defense.").

142. See Bill McAllister, Defense Cites McKinney's Record, WASH. PosT, Mar. 11, 1998, at A2 ("Witnesses ranging from a retired four-star general to privates all testified to McKinney's outstanding military reputation ...."); Interview with Monty Forrester, supra note 39 (stating that the good soldier defense made "a huge difference" for McKinney because of his impressive service record).

143. Military judges can limit cumulative character testimony, but much of this evidence is cumulative by its very nature. For example, McKinney's defense counsel called witness after witness, "ranging from a retired four-star general to privates," to testify to "McKinney's outstanding military reputation." McAllister, supra note 142; see also United States v. Harmon, 40 M.J. 107, 108 (C.M.A. 1994) (holding that the military judge's failure to permit four character witnesses was not an abuse of discretion); United States v. Harris, 34 M.J. 297, 300 (C.M.A. 1992) (involving the submissions of " 19 letters from appellant's colleagues and superiors favorably attesting to his military and personal character, 31 awards and certificates of achievement, and 11 performance evaluations" as good military character evidence). See generally GILLIGAN \& LEDERER, supra note 12, at 779-80 (describing character evidence).

144. Interview with William D.S. Dixon, supra note 39 (characterizing the defendant most helped by good military character evidence as one with years of service); Interview with Eugene R. Fidell, supra note 39 (explaining the great significance of good soldier testimony for a highranking accused); Interview with Monty Forrester, supra note 39 (noting that the good soldier defense has more meaning for court-martial members or a military judge if the accused is high ranking with a long service record); Interview with Robert C. Mueller, supra note 39 (noting that good soldier testimony can be particularly effective for senior persons with unblemished service records).

145. For a brief but informative essay on rank and other aspects of military culture, see Judith Hicks Stiehm, Just the Facts, Ma'am, in Ir's OUR MLITARY, TOO! WOMEN AND THE U.S. MILITARY 60-70 (Judith Hicks Stiehm ed., 1996).

146. See, e.g., United States v. Mitchell, 41 M.J. 512, 516 (A. Ct. Crim. App. 1994) (Russell, $\mathrm{J}$., concurring) (" $[\mathrm{T}] \mathrm{he}$ mere presence of a such a high ranking officer [a major general] in 
the merits of a court-martial, the sworn testimony of an accused's commanding officer ${ }^{147}$ or the affidavit of a decorated non-commissioned officer with wartime service ${ }^{148}$ operates much like the statements of a civilian prosecutor regarding the credibility of witnesses. Official vouching is prohibited in civilian trials because it threatens to replace a jury's reasoned consideration of testimony with appeals to the authority of the state and the prestige of the prosecutor's office. ${ }^{149}$ For the same reasons, neither prosecutors nor defense counsel are permitted to express "personal belief in the guilt or innocence of the accused or the credibility of a witness" 150 during a court-martial. Although military witnesses are not technically officers of the court, their testimony preempts the judgment of a court-martial panel much like a vouching prosecutor would preempt the reasoning of a civilian jury. Advocates of the good soldier defense resolutely insist that the integrity and judgment of senior noncommissioned and commissioned officers lends their character testimony great credibility and weight and that a panel of servicemembers serving on a court-martial is well-positioned to assess such evidence. ${ }^{151}$ They may be right. But that testimony does not belong in a court of law any more than a federal prosecutor's statement that she believes the statement of a cooperating government witness.

The privilege granted those of high rank through the introduction of good military character evidence is not only redundant-soldiers appear in uniform at courts-martial, wearing their rank and ribbons, much like McKinney did at his Fort Belvoir trial-but it masks more subtle privileges of gender and race. ${ }^{152}$ In terms of demographics alone, there are few high-

uniform promised to project vicariously a positive impression of the appellant."); United States v. Humphrey, 4 M.J. 560, 562 (A.C.M.R. 1977) (recognizing the importance of witnesses' rank in holding that testimony was not cumulative, stating that "[p]articularly this is true where the witness is superior in rank to those whose testimony he iterates").

147. See, e.g., United States v. Carpenter, 1 M.J. 384, 386 (C.M.A. 1976) (" [T]he opinion of a serviceman's commanding officer occupies a unique and favored position in military judicial proceedings.").

148. It is not only generals who make persuasive character witnesses. See, e.g., United States v. Williams, 3 M.J. 239, 240 (C.M.A. 1977) (discussing the potential significance of the good soldier testimony of a Chief Master Sergeant with 33 years of service).

149. See, e.g., Rosemary Nidiry, Note, Restraining Adversarial Excess in Closing Argument, 96 CoLUM. L. REv. 1299, 1310 (1996) (describing improper vouching as prosecutorial misconduct).

150. GILLIGAN \& LEDERER, supra note 12 , at 882.

151. Interview with Monty Forrester, supra note 39 (asserting that military character witnesses do not take their responsibilities lightly and that such testimony carries appropriately great weight with a court-martial panel).

152. As McKinney's case demonstrates, the dynamics of race, rank, and gender create a complex set of social and cultural hierarchies within the armed forces. The good soldier defense is one instance where race, gender, and rank can be usefully analyzed-but not resolved into a simple regime of privilege. Though enlisted, McKinney was hardly of low rank. The first African American to hold the highest enlisted post in the Army, McKinney stood at the apex of a massive force of non-commissioned officers and enlisted personnel. He initially blamed the Army's avid 
ranking servicemembers of color, ${ }^{153}$ and fewer still who are women. ${ }^{154}$ The combat restrictions and institutional biases against women that still exist in the armed forces have prevented women from gaining the wartime experience that is most compelling as good soldier evidence, ${ }^{155}$ while African-American troops have historically been singled out for nonconformity and insubordination. ${ }^{156}$ Servicewomen who bring sexual harassment charges are almost always of lower rank than the men they accuse $^{157}$ and therefore appear inherently less reliable before courtsmartial. ${ }^{158}$ Their accusations often pale before a litany of testimony and documentary evidence concerning the accused's remarkable service career, ${ }^{159}$ making it nearly impossible to get a conviction. ${ }^{160}$ Excluding

interest in investigating his alleged misdeeds on the Army's racism and unwillingness to prosecute high-ranking officers. See, e.g., Army Probing Own Investigators: Agents Allegedly Coerced Witnesses, Targeted Blacks in Sex Cases, CHI. TRाB., Mar. 22, 1998, at 15; Charge of Racial Bias Enters McKinney Trial, SAN DIEGo UNION TRIB., Feb. 28, 1998, at A9.

153. See OFFICE OF 'THE ASS'T SECRETARY OF DEFENSE, POPULATION REPRESENTATION IN THE MIIITARY SERVICES B-37 (1997) [hereinafter POPULATION REPRESENTATION] (reporting 2066 black, 407 Hispanic, and 747 "other" [a category including American Indians, Asians and Pacific Islanders, and Native Americans, see id. at 1-3, n.3] persons at the rank of E-9- the highest enlisted rank-compared to 7527 white E-9s in the Department of Defense during fiscal year 1996); id. at B-39 (reporting 43 black, 8 Hispanic, and 8 "other" officers of general rank as compared to 796 white general officers in the Department of Defense during fiscal year 1996); see also Dan Landis et al., The Effects of Race on Procedural Justice: The Case of the Uniform Code of Military Justice, 24 ARMIED FORCES \& SOC. 183, 205-6 (1997).

154. See POPULATION REPRESENTATION, supra note 153, at B-36 (reporting 468 female E-9s compared to 10,279 male E-9s in the Department of Defense during fiscal year 1996); $i d$. at B-38 (reporting 17 female general officers, all but two at the one-star rank, compared to 838 male general officers in the Department of Defense during fiscal year 1996).

155. See HARRELL \& MILLER, supra note 130, at $98-99$ (concluding that women are still significantly limited to less than full participation in the military by official and unofficial restrictions); Kristin K. Heimark, Sexual Harassment in the United States Navy: A New Pair of Glasses, 44 NAVAL L. REV. 223, 229 (1997) (titling a section "The 'Good Sailor': Can Women Ever Measure Up?"); Lucinda Joy Peach, Gender Ideology in the Ethics of Women in Combat, in IT'S OUR MIIITARY, TOO, supra note 145, at 156-94 (describing briefly the history and current status of American women in combat).

156. See supra note 106 and accompanying text.

157. See Lisa D. Bastian et al., Department of Defense 1995 Sexual Harassment Survey (DMDC Report No. 96-014 Dec. 1996), at vi ("For women, 83 percent of junior enlisted reported experiencing uninvited and unwanted gender-related behaviors, compared to 74 percent for senior enlisted and 75 percent for officers."); id. at 20, fig. 9, Unwanted Sex/Gender-Related Experiences by Paygrade of the Target (charting the higher levels of sexually harassing behaviors experienced by junior enlisted personnel as opposed to senior enlisted and officers); id. at. 23, fig. 12, Military Status of the Offender(s) in the One Situation (describing the one reported case of sexual harassment and noting that most-67\%-of harassers outrank their targets, with unit commanders composing $4 \%$, immediate military supervisors $18 \%$, "other military personnel of higher rank/grade" $43 \%$, and military training instructors $2 \%$ of reported harassers).

158. See, e.g., J. Lancaster, In Military Harassment Cases, His Word Outranks Hers, WASH. POST, Nov. 15, 1992, at A1. More pithily, the good soldier defense is not about the accused servicemember's character so much as it is about the character of his friends. I am grateful to Kathryn Johnson for this observation.

159. Other than the McKinney case, courts-martial of drill sergeants at Aberdeen Proving Grounds and after the Tailhook investigation have also involved good soldier testimony and battles of credibility between accusers and an accused. See, e.g., Patrick B. Pexton, Editorial, 
evidence of the accused's good military character would not completely remedy the rank, race, and gender gaps in credibility, but it would be a step in the right direction. ${ }^{161}$

For civilian leaders and military commanders concerned about maintaining good order and high morale among troops, the perception of equal justice under the law is as important as its reality. The impression that rank and gender carry guarantees of immunity from criminal conviction is corrosive to both. ${ }^{162}$ High-ranking servicemembers and those with long military careers are already much less likely to be prosecuted at courtsmartial. ${ }^{163}$ In part, this is because older, more experienced soldiers simply commit fewer crimes that come to the attention of commanding officers. But it is also because the actions of experienced soldiers are more likely to be excused by a commander aware of the risks and sacrifices of long-term military service. Servicemembers accused of military crimes have a constitutional right to present a defense, ${ }^{164}$ but their military and civilian

Persecuted Military Women, WASH. POST, Oct. 10, 1997, at A25 (" [ $]$ t was not the men but the women on trial.").

160. For example, none of the Navy officers accused after Tailhook were convicted of assault. See Heimark, supra note 155 , at 232 n.29.

161. See, e.g., Army Sex Verdict's Chilling Effect: Acquittal May Deter Future Cases, NEWSDAY (N.Y.), Mar. 15, 1998, at A3 ("Legal observers say the military women who watched [McKinney's trial] may be reluctant to bring similar charges in the face of his acquittal."); Letter to the Editor, Army Sgt. Maj. Gene McKinney-Why Should Women Continue To Report Sexual Harassment After Miscarriage of Justice, SEATTLE TMES, Apr. 2, 1998, at B5 ("[W]omen are still considered second-class citizens, especially in the military, as indicated by the outcome of the Army Sgt. Major Gene McKinney trial."); David Wood, Women in Uniform Outraged, Appalled by McKinney Verdict, SAN DIEGO UNION-TRIB., Mar. 22, 1998, at G4 ("Speaking into a rising chorus of jeers, boos and Bronx cheers, senior military leaders are trying to reassure angry women in uniform that they are valued members of the force whose rights and honor will be protected.").

162. See, e.g., Editorial, McKinney Case Showcoses Military Law's Shortcomings, USA TODAY, Mar. 18, 1998, at 12A (criticizing the lack of consistent prosecution of sexual harassment in military courts); Col. John A. Pitchford, Letter to the Editor, Military Justice Incapable of Equal Treatment, USA TODAY, Mar. 16, 1998, at 14A ("[T] he Uniform Code of Military Justice... is totally incapable of dealing with misconduct by senior leaders."); All Things Considered: Fort Hood Reactions, (NPR radio broadcast, Mar. 16, 1998) (quoting an Army captain on the likely success of sexual harassment claims: "[T]he outcome of the Gene McKinney case proves what she's already known ... the more a superior has on his collar, the more he'll get away with.").

163. See supra Part V. The rarity of courts-martial of high-ranking officers and enlisted personnel is immediately clear to even a casual observer of the military justice system. Presumably, many "bad" soldiers are weeded out early in their military careers, creating a higher proportion of "good" soldiers among those who stay in the service and win promotion to higher grades. The fact that older servicemembers may indeed be better soldiers does not rectify the problem of the incoherence of "good military character," nor does it justify the admission of character evidence in the findings phase of a court-martial. See supra Parts III \& IV.

164. See U.S. ConST. amend. VI; United States v. Ingham, 42 M.J. 218, 223 (C.A.A.F. 1995); 10 U.S.C. $\$ 827$ (1994) (detailing an accused's right to qualified counsel in a courtmartial); see also MUELLER \& KIRKPATRICK, supra note 20, at 546-47 ("A criminal defendant has essentially an absolute right to introduce evidence of a pertinent trait of his character during the defense case."). 
accusers have a right to a fair hearing as well. ${ }^{165}$ Rank and hierarchy are inescapable in military justice; there is no need to exaggerate their effects by permitting accused servicemembers to bring their records, rather than their acts, to bear on the guilt phase of a court-martial. ${ }^{166}$

Military judges should consider remedying the illogic and inconsistency of the good soldier defense by using their discretion to limit carefully the admissibility of good military character evidence. ${ }^{167}$ In certain cases, such as those involving military-specific charges like malingering or being absent without leave, placing evidence of good military character before the factfinder makes sense. But in trials for non-military charges, or military-related charges that involve differences of rank, race, and gender between the accused and the victims or accusers, good military character evidence should be excluded. Judges already restrict the use of character in cases involving overwhelming evidence of misconduct, or when charges are especially serious. Raising the bar higher would focus factfinders on acts rather than status, and it would help to correct the impression that high rank bestows near-total immunity from conviction. Senior servicemembers accused of misconduct are allowed to place their thumbs on the scales of justice through the good soldier defense. Military judges should right the balance.

165. Contrary to what the military judge in the McKinney trial stated to the press after the verdict-that the "lesson" of the McKinney case is that victims must report crimes as soon as possible, see Eric Rosenberg, Report Harassment Fast, McKinney Trial Judge Advises, HousTON CHRON., Mar. 24, 1998, at A8-one of the unfortunate lessons of the McKinney trial is that servicewomen who allege sexual harassment are unlikely to get a fair hearing in a court-martial.

166. See 10 U.S.C. $\$ 837$ (1994) (baning unlawful command influence). For a discussion of the role good soldier evidence played in the McKinney case, see Bill McAllister, Defense Cites McKinney's Record, WASH. POST, Mar. 11, 1998, at A2, which summarizes McKinney's counsel Gittins's closing statement that "McKinney's exemplary service record was sufficient alone to raise reasonable doubts about charges that he sexually mistreated six women" and that McKinney's case "is a case about character." Of course, rank will affect military justice so long as a separate legal system exists. Still, the fact that civilian correlates such as wealth and status may enter into a civilian trial does not prevent Article Wl courts from attempting to ensure, via evidentiary safeguards, that justice is not for sale. Likewise, courts-martial should limit the prejudicial effects of an accused's high rank.

167. See MII. R. EVID. 403 (requiring the exclusion of relevant evidence if "substantially outweighed by the danger of unfair prejudice"). 
